\title{
The Islamic Juridical Field in Central Asia, ca. $1785^{-1918}$
}

\section{Introduction}

Before the Russian conquest, Central Asian rulers played a central role in the dispensation of justice according to sharî́a. This phenomenon has long been overlooked, because studies of dispute resolution in the Islamic world, especially in Central Asia, tend to assign greater importance to the legists than to the state - that is, the Muslim ruler and his representatives in court. Students of Islamic law usually hold that the settlement of disputes in Muslim-majority

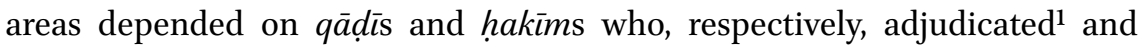
arbitrated $^{2}$ cases independently or facilitated reconciliation by means of mediation, either judicial or extrajudicial. ${ }^{3}$ In the resulting narrative, the state is pushed to the margins of jurisprudence. ${ }^{4}$ Every new monograph on the subject of Islamic law shows that the state provided either a court of second instance, by offering a mazālim appellate system, ${ }^{5}$ or a mechanism of governance

1 J. Schacht, Introduction to Islamic Law (Oxford: Clarendon Press: 1965): 188-98; W.B. Hallaq, The Origins and the Evolution of Islamic Law (Cambridge: Cambridge University Press, 2005): passim; M. Khalid Masud, R. Peters, and D. Powers, "Qādīis and Their Courts: An Historical Survey." In Dispensing Justice in Islam: Qadis and Their Judgements, ed. M. Khalid Masud, R. Peters, and D. Powers (Leiden: Brill, 2006): 1-44. A notable exception to this trend is the work of Mathieu Tillier; see, e.g., his "Judicial Authority and Qādīis' Autonomy under the Abbasids." Al-Masaq:Journal of the Medieval Mediterranean 26/2 (2014): 119-31.

2 On arbitrators, see A. Othman, “And Amicable Settlement Is Best': Șulh and Dispute Resolution in Islamic Law." Arab Law Quarterly 21 (2007): 64-90; W.B. Hallaq, Sharīa: Theory, Practice, Transformations (Cambridge: Cambridge University Press, 2009): 159-64.

3 I. Tamdoğan, "Ṣulh and the 18th Century Ottoman Courts of Üsküdar and Adana." ILS 15/1 (2008): 55-83; P. Sartori, "The Evolution of Third-Party Mediation in Sharîa Courts in 19thand Early 2oth-Century Central Asia." JESHO 54/3 (2011): 311-52.

4 On this approach, see F. Pirie, The Anthropology of Law (Oxford: Oxford University Press, 2013): 97-103.

5 On mazālim, see J.S. Nielsen, Secular Justice in an Islamic State: Mazālim under the Bahrī Mamlūks, 662/1264-789/1387 (Leiden: Brill, 1985): 9. On the role of the state in conflict resolution in the Ottoman period, see Y. Ben-Bassat, Petitioning the Sultan: Protesters and Justice in Late Ottoman Palestine (London: I.B. Tauris, 2013): 24-8. 
that affected legal hermeneutics, ${ }^{6}$ by which it ultimately constrained juristic independence. ${ }^{7}$ This narrative creates an artificial opposition between the Islamic state and sharía, an opposition predicated on the notion of Islamic law as the exclusive preserve of Muslim legists ( ulam $\bar{a}$ ) — that is, as a self-contained juristic domain inaccessible to the uninitiated. Materials from nineteenth- and early-twentieth-century Central Asia call into question this binary interpretive model, shedding light on an Islamic legal system in which Muslims brought their affairs to state officials because they had the power to coerce parties to achieve a settlement and enforce a decision, either formal or informal. A clear sense of hierarchy rather than a notion of jurisdiction informed Muslims' choices to take legal action. Indeed, in the Islamic legal system reflected in the records originating from local Muslim chancelleries, $q \bar{a}$ ḍis rarely adjudicated, acting, instead, primarily as notaries and legal assessors, while responsibility for the resolution of conflicts fell on the rulers and the governors. Individuals appealing and adjudicating did not see two different legal standards (the Islamic state and sharîa). The same personnel resolved all types of problems, and there is little, if any, specific reference to specialized legal texts. When they adjudicated disputes, $q \bar{a} d \bar{c} \bar{s}$

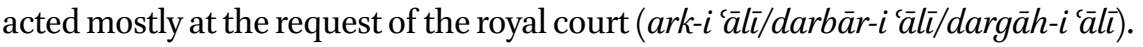

Interpreting the legal history of nineteenth-century Central Asia requires that we avoid assuming that the institutional arrangements and the judicial systems current elsewhere in the Islamic world were adopted also in this region, before the establishment of Russian rule. If one keeps, for instance, the Mamluks or the Ottomans as some kind of Archimedean points to tackle the history of sharía in the modern period, one will regard the Central Asian case as aberrant. This is not, however, a particularly helpful approach, because it leads us to believe that there are some stages in the evolution of Islamic law that are more representative than others and that there are cases that may speak more authoritatively about what we term sharía than other cases regarded as less integral to the tradition of Islamic law. As the reader will see, there was little in common between how conflicts were solved in Bukhara under the Manghits and, say, Ottoman Egypt and Qajar Iran, aside from the obvious commonalities in Islamic legalese, that is, in the vocabulary employed mostly by Muslim jurists. ${ }^{8}$ Although institutions may seem similar at first, a closer look

6 G. Burak, "The Second Formation of Islamic Law: The Post-Mongol Context of the Ottoman Adoption of a School of Law." cssh 55/3 (2013): 579-602.

7 Hallaq, Sharīa: Theory, Practice, Transformations: passim.

8 I owe this idea to F.H. Stewart, "False Friends: Overlapping Terminology in Arab Customary Law and in Islamic Law." Paper delivered at the 6th Conference of the International Society for Islamic Legal Studies, Exeter, 13 July 2009. 
at the administrative practices, the language, and the legal literature employed suggest that there are fewer similarities than differences. While comparisons open up interesting possibilities to establish connections and a world of shared cultural references, they also lead one to confer normative value on one of the two comparators. If, say, one considers Ottoman agrarian history, practices in property relations in the Persianate world will always be examined in the light of the lessons we have learned from studying, say, Anatolia or Syria, thereby risking our misinterpreting the specific attributes of the Central Asian cases in hand. My approach here is different. Rather than focusing on reified Islamic legal institutions as such, I offer an exploration of practices of dispute settlement in a specific region of the Islamicate world. The legal history of nineteenth-century Central Asia, a region where, for example, rulers did not avail themselves of mazālim, differed considerably from the histories of Islamic law in other regions.

While my study is firmly grounded on material originating almost exclusively from southern Central Asia, it also addresses the cumulative experience of a wider academic enterprise that began more than two centuries ago to write the history of Islamic law. In assuming that law was a privileged domain of professional legists, historians of Central Asia commonly echo an assumption integral to the tradition of Islamic legal studies in the West. For obvious reasons, Central Asia has been relegated to the margins of the discipline. In what follows I want to suggest that it also offers a stepping stone to rethinking the way we read (and write) the history of shari $a$ in the post-Mongol period, especially in wider Persianate history. This study is based primarily on sources from nineteenth- and early-twentieth-century Central Asia. These sources were produced in the chancelleries of the local Muslim polities before the Russian conquest and during the period in which the Bukharan emirate and the Khivan khanate fell under Russian protectorate. Further explorations in materials from earlier periods will probably show that the legal culture that I illustrate here existed in the region before the establishment of the three Uzbek khanates and, perhaps, in other regions of the Islamicate world as well.

Imagining a legal system in which the ruler and his chancery exercise legal authority and dominate legists, arbitrators, and mediators requires the application of an inclusive concept, a spatial metaphor allowing for the inclusion of a plurality of legal actors. I find one such concept in Pierre Bourdieu's notion of "juridical field." In his understanding, a juridical field "is determined by two factors: on the one hand, by the specific power relations which give it its structure and which order the competitive struggles (or, more precisely, the conflicts over competence) that occur within it; and on the other hand, by the internal 
logic of juridical functioning which constantly constrains the range of possible actions and, thereby, limits the realm of specifically juridical solutions." ${ }^{\text {9 }}$

This notion is not entirely without problems. Bourdieu conceives of the juridical field as a system of power relations as well as a discursive space that is shaped exclusively by individuals who have judicial authority, that is, the legal experts. In other words, he assumes that nonexperts can be only passive recipients of legal supply and excludes the possibility that laymen too may partake in the conflicts over competence and thus affect the quality of legal services. My employment of the notion of "juridical field" differs from that of Bourdieu. I believe that people have expectations when they approach legal institutions, that they make assumptions about their entitlements, and that they thus have clear ideas about the truth of the claims that they present, originating, as these do, from the experience and knowledge that they accumulate during their lives. When I speak of the juridical field, I imagine a space in which the lawat the level of both imagination and patterned behavior-is the outcome of the relations between individuals endowed with legal authority and those who seek redress. The juridical field thus becomes a spatial metaphor to embrace law and society.

Richard Terdiman, who translated the work of Bourdieu into English, has noted that the notion of the "juridical field" becomes particularly effective if we can imagine "a magnet exerting a force upon all those who come within its range." 10 As I argue throughout this chapter, in Central Asia the magnet may be seen in the royal court, which animated a constellation of legal actors and judicial venues and pulled its subjects towards the seats of power, that is, Bukhara, Khiva, and Kokand. When examining behavior, social interactions, and order in this region before the Russian conquest, we see what might be termed a sharîa-informed juridical field, in which many turned to the ruler for redress or approval. This juridical field was a cultural space in which the ruler was perceived, in accordance with the Perso-Islamicate theory of kingship, as guarantor of the just application of shari $a$. The Perso-Islamicate theory of kingship demanded that rulers embody an ideal of Islamic justice ('adālat) and be always accessible to the populace. The Orientalist Aleksander Semenov, who served for several years in the Russian residency in Kagan (a settlement 87): 816 . 
located few kilometers southeast of Bukhara) and therefore had access to the chancellery of the Bukharan Protectorate ${ }^{11}$ noted that:

In spite of his [the emir's] inaccessibility to his people and his vast governing apparatus consisting of bureaucrats and officials of different ranks, who, as it would seem, could fulfill their functions independently within the limits of their competencies, in fact nothing was done without the sanction of the emir. At least, they would account to him nearly every trivia of ordinary administration and everyday life. [...] For among the duties of the Emir, as a just and independent ruler, was not only to ensure the enforcement of punishments, but also the administration of justice [otpravlenie pravosudiia], the Emir himself received appeals and hear cases. ${ }^{12}$

In applying the concept of an Islamic juridical field, I attempt to move away from the theory, discussed in the introduction, of "legal pluralism." Legal pluralists assume that, while modern states claim for themselves legislative prerogatives and try to impose normative standards on societies, behavior reflects the interactions within a semi-autonomous social field and conveys notions of justice that are often at odds with state law. ${ }^{13}$ This approach is no doubt helpful when we study colonial and postcolonial situations and Western societies where more than one body of law is in effect, jurisdictions are delimited, and formalism is a given. It is less useful when we consider societies in the past, which either did not fall under the direct control of a state ${ }^{14}$ or were ruled by dynasties lacking any legislative powers and that did not distinguish between various bodies of law (for example, Islamic law vs. customary law) or different legal doctrines (sing. madhhab). Nineteenth-century Central Asia presents one such case, because sharīa was not the emanation of the legislative will of the khanates, and the people taking legal action did not seem to

11 B.A. Litvinskii and N.M. Akramov, Aleksandr Aleksandrovich Semenov (nauchno-bibliograficheskii ocherk) (Moscow: Nauka, 1971): 43-44.

12 A.A. Semenov, Ocherk ustroistva tsentral'nogo administrativnogo upravleniia Bukharskogo khantsva pozdneishego vremeni (Stalinabad: Izdatel'stvo Akademii Nauk Tadzhikskoi ssR, 1954): 24, 32.

13 F. Pirie, "Legal Autonomy as Political Engagement: The Ladakhi Village in the Wider World." LSR 40/1 (2006): 77-103.

14 J. Scheele, "Rightful Measures: Irrigation, Land, and the Sharīah in the Algerian Touat." In Legalism: Anthropology and History, ed. Paul Dresch and Hannah Skoda (Oxford: Oxford University Press, 2012): 198. 
have perceived different legal institutions as representing legal diversity. They did not understand sharita in opposition to customary law. The subjects of the khans could and did shop for different legal forums - that is, they brought their affairs to different institutions such as the ruler (his court), the governor, the $q \bar{a} d \bar{\imath} \mathrm{s}$, or the local notables-but they did not regard such institutional actors as embodying diverse bodies of law, nor did they seem to regard existing procedural differences as particularly important in choosing among the existing legal venues. In spite of different procedural attributes, people perceived such institutions as representing the totality of the parts that constituted sharíta.

Legal pluralists may disapprove of my approach, by arguing that I am overlooking the fact that the legists and the scholars distinguished between shari $a$ and 'urf, 'ādat, dastūr ("custom") and ta'amul, 'amal ("practice"); that such distinctions could have informed laymen's understanding of legal practice; and that such notions about procedural differences may also have informed their choices. While I do not want to rule out this possibility, I have used a different methodology in this book. I have employed local legal notions as they appeared in my sources without projecting on my information any preconceptions about Muslim legal practice. Nothing in my sources suggests that, in precolonial Central Asia, Muslims navigated the Islamic juridical field by keeping in mind notions of legal diversity, thereby creating an opposition between customary norms, local practice, and Islamic law. When appealing to a local governor, for example, a subject of the khanate might have known that a governor could resort to violence (siyāsat) in order to extort a confession; equally, this appellant might have been aware that it would have been unlikely that a $q \bar{a} d \bar{\imath}$ would use violence against parties to a dispute. Does this represent a case of legal diversity? The answer must be "no," because our sources tell us that both the governor and the qā $\bar{l} \bar{\imath}$ solved disputes according to sharīa and did not distinguish between, say, the law of governors and that of judges. Islamic legal sources are "aspirational," one would say, because they make resolutions to conflicts appear as though they were always achieved in compliance with sharîa, thereby effacing substantial differences. However, rather than interpreting the aspirational character of Islamic legal sources as an obstacle to our unveiling a world of assumed legal diversity, I suggest instead that we reflect on the fact that our sources originate from a juridical field informed by an inclusive notion of sharîa - a juridical field that could accommodate multiple legal authorities and institutions, which, as we shall see, often displayed overlapping jurisdictions and shared many legal functions. If this is what the available sources indicate, one wonders what would be the interpretive advantage of superimposing upon them a reading that downplays the significance of such inclusiveness. 
The fact that, in precolonial Central Asia, the local population shopped for different legal forums actually indicates a situation of multiple jurisdictions and, therefore, a case of legal pluralism. From this perspective, one would understand legal pluralism more as a "jurisdictional web" than as interlocking normative orders. ${ }^{15}$ This approach is a useful reminder of the complexities and contradictions of what we usually term "state law". As we shall see in greater detail in this chapter, in the 19th century, Central Asian khanates relied on various legal institutions to dispense justice. We should, however, be careful not to conflate jurisdictional plurality with legal diversity, for the two are different. Indeed, while in Central Asia Muslim dynasties created a plurality of legal institutions, such institutions were not substantially diverse because they all aspired to implement Islamic law.

The process of unpacking the ideological underpinnings of such a juridical field becomes particularly important as we set out to appreciate the discontinuities and the changes that Central Asian Muslims experienced in the wake of the Russian conquest. We must look critically at the conceptual repertoire of studies on law, colonialism, and globalization. It has been argued that, "when the Russians formed the governor-generalship of Turkestan there between the 1860 s and early 188 os, they encountered Muslim communities [...] who had long made temporal authorities central actors in the mediation of these disputes."16 As we shall see, this observation requires further clarification. Central Asian Muslim subjects did not regard emirs and khans as merely "temporal authorities," nor did they conceive of sharía as a legal system informed by theology alone. As I hope to show, Central Asian rulers exercised Islamic judicial authority with little apparent concern for the presumed divine origin of sharita.

Another idea that has gained some currency is that locals turned to rulers, hoping "to challenge the judgments of Islamic law court judges."17 This view too is confusing, because there is little evidence of the use of judicial review in precolonial Central Asia. In conferring utility on this interpretation, one

15 This approach to the study of legal pluralism has been elaborated in L. Benton, Law and Colonial Cultures: Legal Regimes in World History: 1400-1900 (Cambridge: Cambridge University Press, 2002) and L. Benton and R.J. Ross, "Empires and Legal Pluralism: Jurisdiction, Sovereignty, and Political Imagination in the Early Modern World." In Legal Pluralism and Empires, 1500-1850, ed. L. Benton and R.J. Ross (New York: New York University Press, 2013): 3-7.

16 Crews, For Prophet and Tsar: 250. A similar interpretation has been articulated in Russian Rule in Samarkand, 1868-1910: A Comparison with British India: 246, where Morrison uses the expression "secular authorities."

17 Crews, For Prophet and Tsar: 251. 
lends credit to a colonial cultural construction that considered the royal court only as a site of appeal. As we shall see, Central Asians usually brought their cases before the rulers, not just when they intended to complain about $q \bar{a}$ dì s' malpractice. $^{18}$

I thus want to take categories such as "state law" or "non-state law" less as a given than as reflecting modern Western forms of governance. The question I pose in this chapter is, how can we account for a centralised administration of $\operatorname{shari}^{-} a$ in the region without recourse to the usual interpretative paradigm of "modernization"? I will propose an answer to this question by arguing that, in the Central Asian khanates, the administration of sharía constituted legal sovereignty, thus reflecting what we may term a "sharîa rule of law." By introducing the notion of the rule of law, I want to emphasize the lived experience of law rather than legal theory. The sharía rule of law manifests itself less in the theory of the ruler's integrity ${ }^{19}$ than in the commoners' belief that justice emanates from the royal court. This is something different from consent or obedience. I will try to account for the existence of a state of order in which behavior conforms to the law and forms of legal consciousness are "created by plebeians' own encounter with [...] occasional just outcomes."20

The Islamic Juridical Field in Nineteenth-Century Central Asia

\subsection{Rulers and Judges}

We start with a few considerations regarding the institutional arrangements that made possible the practice of sharīa in Central Asia. First of all, the appointment to legal offices depended, as a general rule, on the sovereign ${ }^{21}$ and

18 My approach here differs from that in Crews, For Prophet and Tsar: 250, and Morrison, Russian Rule in Samarkand, 1868-1910: A Comparison with British India: 246.

19 R. Murphey, "Mustafa Safi's Version of the Kingly Virtues as Presented in His Zübdet'ül Tevarih, or Annals of Sultan Ahmed, 1012-1023 A.H./1603-1614 AD" In Frontiers of Ottoman Studies, ed. C. Imber and K. Kiyotaki (London: I.B. Tauris, 2005): 1:5-24.

20 L. Benton, "Not Just a Concept: Institutions and the 'Rule of Law." JAS 68/1 (2009): 119.

21 That appointment to the office of $q \bar{a} d \bar{\imath}$ depended on the ruler is a constant feature of Sunni legal history; see M.I. Calero Secall, "Ruler and Qāḍīs: Their Relationship during the Nașrīd Kingdom." ILs 7/2 (2000): 235-55. This opened up several issues, among them that, in Sunni judicial theory, the validity of the judicial activity of judges appointed by the de facto political power is a sine qua non, even if that power is illegitimate; see Schacht, Introduction to Islamic Law: 187 . In practice, the ruler might rely indirectly on public opinion to check the qualifications of a candidate; see U. Rebstock, "A Qād $\vec{\imath} \mathrm{s}$ Errors." ILS 6/1 (1999): 1-37. 
entailed choosing among a pool of competing candidates. It was customary during the tenure of the Bukharan emir 'Abd al-Ahad (1885-1910), for example, that appointees to judicial positions were selected from among the offspring of Bukharan scholarly families (makhdhüm-zädigān), while governors and waqf administrators were chosen from among the ruler's allies $(a q r i b \vec{a}){ }^{22}$ Nineteenth-century Bukharan jurists looked favorably on the fact that $q \bar{a} d \bar{\imath} \bar{s}^{\prime}$ investiture (taqallud) depended on the ruler (al-sultān), regardless of whether the ruler was just, cruel, or infidel. ${ }^{23}$

Appointments followed established patterns of reciprocity embedded in a culture of gift exchange. An individual could be rewarded with a designation to office either for his merits or, more often than not, for his display of loyalty and generosity to the emir. A local observer of these practices, Hamīd Khwāja b. Baqā Khwāja, who was born to a Bukharan family of 'ulamā', provides an interesting account of the grand celebrations (tüy) that the local legists organized in honor of the emir. The rule for such events in Bukhara was that the bigger a celebration was, the better the chance that the ruler would confer an office upon its organizer. Hamīd Khwāja was proud, for example, that his father, Baqā Khwāja, the Bukharan chief judge (qa dì kalān), could organize one such tūy for the emir 'Abd al-Ahad that lasted more than a month. ${ }^{24}$ Ḥamìd Khwāja illustrates with humor how his father's acolytes, especially the mullahs, joined the event "to inspect the service at the celebrations" (ba-tüy mutarașsid-i khidhmat shudand). This is, no doubt, the author's ironic twist alerting us to the scholars' obsequiousness towards the chief judge. Hamīd Khwāja took particular pains to explain that all the mullahs attended the event in the hope of royal favor: "nobody knows if the [benevolent] eye of the emir falls [on someone] and satisfies [his] wish [for appointments]" (mabādā ki chashm-i amì äftāda pursish hâal kunad), he tells us. ${ }^{25}$ And the shrewdest among these celebrations' attendees could necessarily capitalize a lot: Ḥamīd Khwāja noted that some of his

22 Ḥamīd Khwāja, Tanzīl al-imthāl fì dhikr bayān al-aḥwāl, MS Tashkent, TsVRUz, no. 6o2: 254 b.

23 The opinion is to be found in a Bukharan legal miscellany titled Majmū'a wa ta'rīkh-i Mullā-zāda, Ms Tashkent, TsVRUz, no. 9767: fol. 37b. This opinion quotes a fifteenthcentury juristic authority, saying "The judicial investiture from an equitable and despotic ruler is licit. But his [the judge's] equitable nature must be manifest" (taqlïd-i qaḍa az sulțān-i 'âdil wa jābir jā̉iz ast ammā az 'ādil-i khwud zāhhir ast), Ikhtiyār al-Dīn b. Ghiyāth al-Dīn al-Ḥusaynī, Mukhtār al-ikhtiyār 'alā al-madhhab al-mukhtār. Ms Tahskent, TsVRUz, no. 5438: fols. 13b; Ms Bodleian, Frazer 239: fols. 4b-5a. The Mukhtār al-ikhtiyār devotes an entire section to appointment (taqlìd) to and removal ('azl) from the office of $q \bar{a} d \bar{c} \bar{c}$. Ḥamīd Khwāja, Tanzīl al-imthāl fì dhikr bayān al-ahwwāl: 255b.

25 Ibid. 
sharp-elbowed contemporaries benefited much more than he did. While the chief judge received from the emir a courier and a golden stirrup, our author could amass nothing more than a robe of honor. ${ }^{26}$ Little wonder that some, by entering the emir's inner circle and organizing ever larger celebrations, managed to secure appointment to the most celebrated judicial position. This was the story, for instance, of Mullā Burhān al-Dīn. This man was ra'is ("chief, market inspector") of Bukhara from 1900 until 1910, when he was accused of having instigated Sunni-Shici clashes in the city. ${ }^{27} \mathrm{He}$ then fell into disgrace and was demoted to the office of judge in the southwestern province of Chahār Jūy (present-day Charjuy, in Turkmenistan). ${ }^{28}$ By exploiting his friendship with the emirate's "treasurer" (khazinachī), he secured permission from the emir in 1913 to hold a new celebration including more invitees, ${ }^{29}$ the cost of which, interestingly, would be borne by the chief judge, Baqā Khwāja. The outcome of this display of extravagance proved successful: Mullā Burhān al-Dīn was sent back to Bukhara on account of his skills in squandering the emir's money. ${ }^{30}$ Indeed, Hamīd Khwāja sardonically reports that his father alarmed another Bukharan legist, saying, "With this feast Mullā Burhān al-Dīn is going to eat either my head or yours! Unfortunately, in the following days it became manifest that he was appointed chief judge." ${ }^{31}$ Mullā Burhān al-Dīn's appointment to chief judge brought about the demotion of Baqā Khwāja to the rank of shaykh al-Isläm, which was, at that time, only an honorary office.

One should, of course, situate this disparaging account offered by Ḥamīd Khwāja in the latter's personal history - that is, the history of someone who, like others in the emirate, ${ }^{32}$ attempted unsuccessfully to get hold of an administrative post. As we shall see later, such positions provided for a stable income stream, not only because they often involved prebends of various sort (as well

\footnotetext{
26 Ibid.: 256b-257a.

27 This episode is recounted briefly in The Personal History of a Bukharan Intellectual. The Diary of Muhammad Sharīf Șadr-i Ziyā, trans. R. Shukurov and ed. E. Allworth (Leiden: Brill, 2004): 299. For more on Sunni- Shici clashes, see A. Khalid, "Society and Politics in Bukhara, 1868-1920." CAS 19/3-4 (2000): 367-96.

28 The Personal History of a Bukharan Intellectual: 257.

29 Ḥamīd Khwāja, Tanzīl al-imthāl fì dhikr bayān al-aḥwāl: fol. 257 a.

30 Ibid.: 257b-258a. This episode is recounted briefly in The Personal History of a Bukharan Intellectual: 299 .

31 Ḥamīd Khwāja, Tanzīl al-imthāl fì dhikr bayān al-aḥwāl: fol. 258a.

32 For another (unedifying and far less detailed) story of repeated attempts to climb the ladder of the judicial hierarchy, see Mīr Sayyid Muhyī al-Dīn b. Mīr Sayyid Hạabībullāh Fathābādī, Khāțirāt, ms Tashkent, TsVRUz, no. 328/IV.
} 
as estates and fiscal privileges) but also because of the gifts (tärtīq/pish $-k a s h)$ that appointees received in exchange for their services. Little surprise that most local scholars longed to be appointed to such a position. In fact, the last decades of Manghit rule over Bukhara saw a strong outburst of factionalism between two groups of scholars, referred to in the local lore as "mountaineers" and "the urbanized" (kuhistānī/khațlānì and tūmānì) according to their place of origin, who competed with each other for supreme authority and for a monopoly on the money-making possibilities of offices. ${ }^{33}$ There is little doubt that the alternate fortunes of this or that scholar reflected personal ties to the emir as well as the latter's strategies. ${ }^{34}$ Hamìd Khwāja was-together with other individuals of distinguished pedigree such as Ṣadr-i Diyā, whom we shall encounter later-among those who had often to endure the ruler's changing will.

The person and office of ruler played an important role also in the ritual whereby powers were conferred upon judicial appointees. The conferral of powers to a judicial post usually occurred according to a strongly ritualized protocol in which officeholders were entrusted with a diploma (yārlīq/ manshür) in front of other court attendants. While all these records share a formulaic nature, they show the extent to which ruling houses defined the jurisdiction as well as the specific duties of its judicial personnel. The royal courts not only determined the fees that judges could charge their clients, but they could also, at times, confer on the new appointees particular powers. If $q \bar{a} d \bar{c} \bar{s}$, for example, could enforce retaliation or other punitive offenses, it would be made explicit in the diploma of appointment. It did not follow, however, that $q \bar{a} d \bar{l} \bar{s}$ always enjoyed such powers. Indeed, the reader will not find the same attributes among those enumerated in other diplomas issued for the post of judge (see Appendix I). Making explicit specific judicial attributes was probably a response to social circumstances and fluctuations in judges' authority in a given locale. We shall see later that, in their areas of jurisdiction, legists often encountered resistance to their judicial functions, and the official endorsement of the royal court may thus have proved necessary in order to secure obedience.

33 The first to offer a clear, if brief, account of this struggle was S.A. Dudoignon, "Les 'tribulations' du juge Ziyā. Histoire et mémoire du clientélisme politique à Boukhara (18681929)." AHSS 59/5-6 (2004): 1095-135.

This is clearly exemplified by the various accounts of appointment and dismissal of judicial officials in The Personal History of a Bukharan Intellectual: passim. 
Appointment as judge consisted, above all, in the ceremonial conferral of these diplomas. The new officeholder would kiss the diploma of appointment, rub it on his eyes, and then stick it in his turban. ${ }^{35}$ The physical attributes of such records suggest that they were designed for display. More often than not, especially in cases of appointment to judicial posts in important urban contexts, diplomas were partially adorned with illuminated lettering and stamped with the seals of the ruler (see Fig. 2).

During this public performance the attendants prayed for the wellbeing of the ruler, and the people could meet the newly appointed legist. The subjects were thus, in general, probably fully aware of changes in legal offices, and such appointments were probably perceived by the populace as reflective of a political statement and the reconfiguring of new power relations: this judge is the man close to the ruler, not the one who has been removed from office. Sources tell us that jurists in disfavor were more likely to be packed off to the less attractive areas, such as the Turkmen steppe, than to Bukhara. The famous Muhammad Shariff-Jān Makhdūm, alias Șadr-i Diyä (1867-1932) — himself a jurist born into a family of Ersari Turkmens that had fled from the Charjuy province to Bukhara and there found its fortunes ${ }^{36}$-refers to the appointment to the post of chief judge of Mullā Șadr al-Dīn b. Bayḍā, a mullah from the mountainous region of Kulab (in present-day Tajikistan, hence his nisba Khațlānī, "mountaineer"). ${ }^{37}$ This

35 Qāḍī Muḥammad Wafā Karminagī, Tuhffat al-khānī, ms Tashkent, TsVRUz, no. 16: fol. 264b (ināyat-nāma-yi shahriyār-ra bar sar-i ū nishānda). My thanks to Andreas Wilde for this reference. It was the parvānachī-yet another among various administrative figures whom we could term "chamberlain" — who usually stuck the diploma in the new appointee's turban; see N.V. Khanykov, Opisanie Bukharskogo Khanstva (St. Petersburg: Tip. Imperatorskoi Akademii Nauk, 1843): 185. See also Șadr al-Dīn 'Āynī, Bukhārā inqilābīning ta'rīkhī, ed. S. Shimada and S. Tosheva (Tokyo: Dept. of Islamic Area Studies, Center for Evolving Humanities, Graduate School of Humanities and Sociology, University of Tokyo, 2010): 22 (amīrnìng yārlīghīn bāshīgha sūqūb). Sticking a diploma in the appointee's turban applied to several officeholders, tax collectors (amläkdār) included; see TsGARUz, f. I-126, op. 1, d. 746, l. 83 .

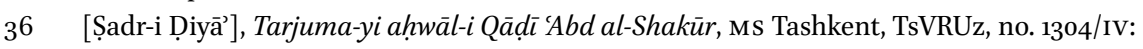
fol. $98 \mathrm{~b}$.

37 For more on this person and the impact his appointment is presumed to have had on the office of chief justice in the cultural environment of Bukhara, see The Personal History of a Bukharan Intellectual: 105 fn. 81 . 


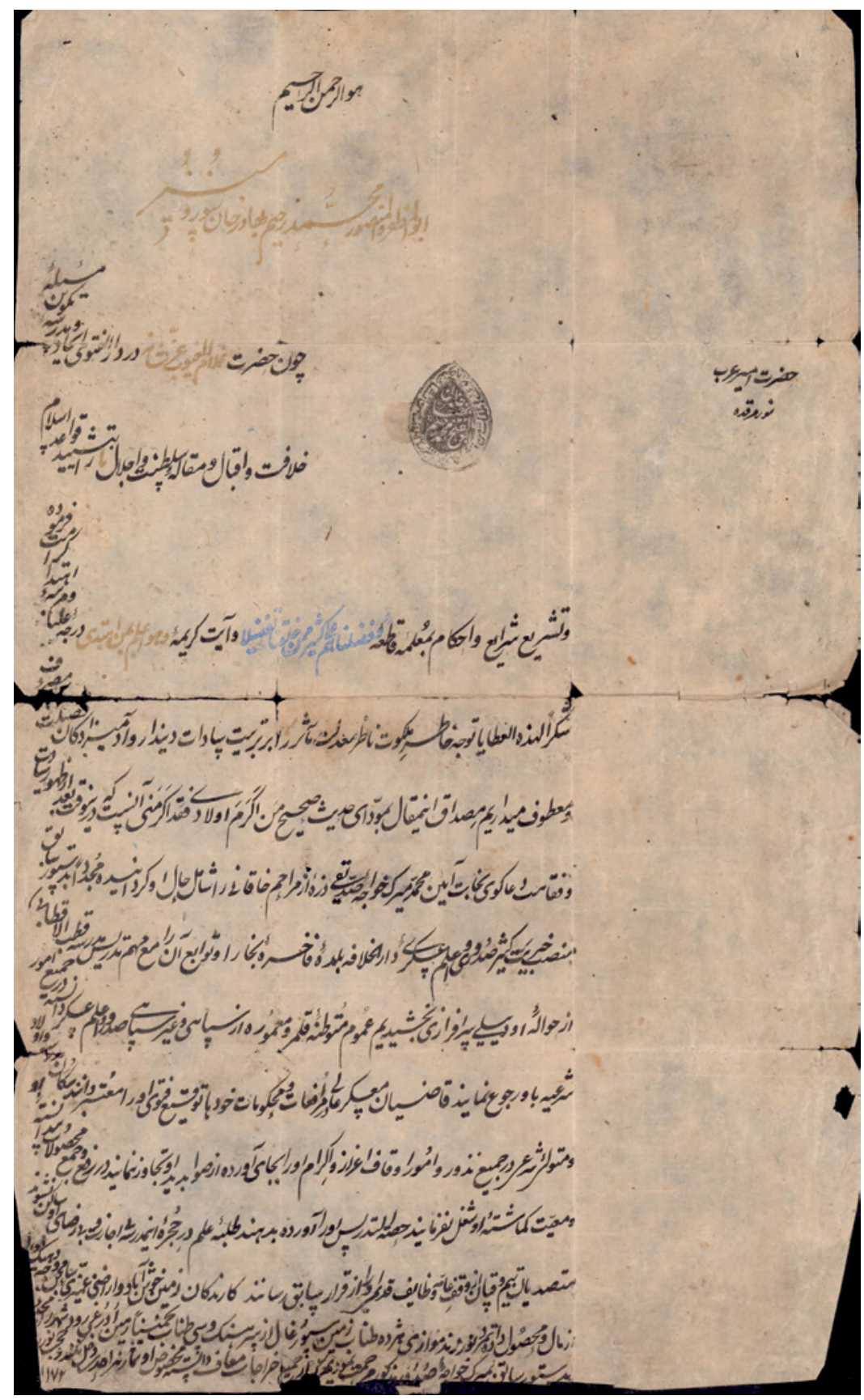

FIGURE 2 Diploma of appointment to the position of senior jurist for the military (șudūr/a'lam-i 'askarī) issued by Muhammad Raḥim Khān, Bukhara, 1172/1758-9. TsGARUz, f. R-2678, op. 2, d. 177, unnumbered folio. COURTESY OF THE CENTRAL STATE ARCHIVE OF UZBEKISTAN 
appointment was followed by the subsequent removal of eighteen officials (including his father) from other legal posts and their reappointment to judicial positions in the countryside (az Bukhārā ba wilāyāt wa tūmānāt qā kunānīda). ${ }^{38}$ The account of Șadr-i Diyāa indicates how such dismissals were often loaded with political meaning for networks of scholars in the emirate. Șadr-i Diyā' also glosses at length the decision as one affecting directly the way in which justice was dispensed and even how law was taught in the institutes of higher learning. ${ }^{39}$

In addition to conferring powers on candidates for the post of $q \bar{a} d \bar{i}$, the ruler stood atop the judicial hierarchy. In the wake of a homicide case, for instance, Qāḍī 'Abd al-Shakūr (1817/8-1889), ${ }^{40}$ the father of Șadr-i Dịāà, informed Emir Muzaffar al-Dīn (r. 1860-86) of his decision to proceed with a sentence of retaliation (qișass), which consisted of the corporal punishment of the murderer. Before approving the decision, the cautious emir submitted it to the chief judge in Bukhara, Qāḍ̄ 'Abd al-Shakūr's archenemy, the aforementioned Șadr al-Dīn. The two qādìs stood in a hierarchical relation: the chief judge had the monopoly over homicide cases. ${ }^{41}$ The qā retaliation and recommended that his sovereign order the payment of blood money (diyat). Notified of this decision, Qāḍī 'Abd al-Shakūr vehemently protested and rallied other jurists in the city. Two rulings on the same case were now brought before the emir: persuaded by the urban judicial community, the ruler rejected the sentence of compensation and upheld that for retaliation. Once he received the confirmation from Bukhara, the judge in the countryside was happy to enforce a legal order according to sharía.$^{42}$ If law is about choosing between right or wrong, however, we should also note that, in several cases, it was the ruler, not the $q \bar{a} d \bar{l}$, who ultimately imposed the judgment. Such cases may well have involved disputes on more mundane affairs than homicide cases, such as those involving property rights and fiscal privileges. It was common, for example, for Bukharan rulers at the beginning of the nineteenth century to issue rulings ( $h u k m-i$ 'a $l i)$ conferring on someone ownership rights

\footnotetext{
38 Tarjuma-yi ahwāl-i Qāệ̄ Aabd al-Shakūr: fol. 101a-b.

39 Ibid.: fol. 101b.

40 The Personal History of a Bukharan Intellectual: 85 fn. 5 .

41 See Appendix I.

42 Tarjuma-yi aḥwāl-i Qā ḍ̄ 'Abd al-Shakūr: fol. 102a-b.
} 
over a certain amount of land after court attendants had carried out inquiries into disputes. ${ }^{43}$

\subsection{Appealing to the Royal Court ('arḍ)}

It is conventionally assumed that the job of $q \bar{a}$ dìs was always to adjudicate disputes, but surprisingly few sources provide information about the exact nature of their responsibilities. Starting in the early Soviet period, a vast number of Islamic legal records stemming from the post-Timurid period has been published or described in catalogues. To date, however, records illustrating the process of adjudication and delivery of a ruling $(\mathrm{hukm})$ are extraordinarily rare. ${ }^{44}$ In Central Asian Islamic legalese, such records are called sijill, and they serve a specific documentary purpose. They were usually issued to the parties to a dispute and were treated as a written attestation of the outcome of a litigation and the entitlements that the latter generated. ${ }^{45}$ Thus, in nineteenth-century Central Asia the understanding of the word sijill was closer to that of the term used under the Mamluks, and it should not be conflated with the Ottoman

43 Mīrzā Ṣādiq Munshī Jāndārī, Munsha’āt wa manshūrāt, Ms Tashkent, TsVRUz, no. 299: fol. 124a.

44 Only two specimens of such legal texts have been published so far, though more are known to have existed and have been occasionally catalogued; see Samarkandskie dokumenty XV-XVI vv. (O vladeniiakh Khodzhi Akhrara v Srednei Azii i Afganistane), ed. O.D. Chekhovich (Moscow: Nauka, 1974): docs. 14 and 15, 303-10. I have located similar texts in TsGARUz, f. I-125, op. 1, d. 602, ll. 1-10b and TsVRUz, Khiva qozilik khujjatlari (Aklia Aliakbarova's collection), doc. 16a, 71, 583, 645, 675, 685. The latter were described briefly, under the same numeration, in Katalog Khivinskikh kaziiskikh dokumentov (XIX-nach. $X X v v$.), ed. A. Urunbaev et al. (Tashkent and Tokyo: Department of Islamic Area Studies, 2001).

45 Ol'ga Chekhovich renders sijill as “deed of attestation' (podtverzhdaiushchii dokument) in Samarkandskie dokumenty XV-XVI vv. (O vladeniiakh Khodzhi Akhrara v Srednei Azii $i$ Afganistane): 305 . The term sijill is also to be found among the stipulations of endowment deeds (sing., waqfíya or waqf-nāma). The term refers to a document attached to endowment deeds as a result of a fictitious claim for the recovery of property that the endower filed against the endowment. Thus, such a document too functions as a written attestation of the outcome of a dispute. On such fictitious claims and stipulations of Central Asian endowment deeds, see K. Isogay, "A Commentary on the Closing Formula in the Central Asian Waqf Documents." In Persian Documents, ed. N. Kondo (London: RoutledgeCurzon, 2003): $3^{-12}$. See also Bukharskii vakf XIII v. Faksimile. Izdanie teksta, perevod s arabskogo i persidskogo, vvedenie i kommentarii A.K. Arendsa, A.B. Khalidova, O.A. Chekhovich (Moscow: Nauka, 1979): 24, where it is glossed as "deed of official confirmation' (akt ofitsial'nogo utverzhdeniia) and M.E. Subtelny, Timurids in Transition: TurkoPersian Politics and Acculturation in Medieval Iran (Leiden: Brill, 2007): 150, where it is translated as "endorsement." 
usage as "qā before colonization —or, at least, not a single register from a period preceding the Russian conquest is known to have survived. ${ }^{47}$

Sijills appear infrequently, and, when they do, it is usually in private collections. For some reason, they pertain most often to cases involving animal theft. The fact that $q \bar{a} d \bar{c} \bar{s}$ in the nineteenth century apparently issued sijills only within a narrow range of circumstances seems to reflect the restriction of the judicial powers of $q \bar{a} d \bar{l} \bar{s}^{\prime}$ under the rule of the three Uzbek khanates that were established at the end of the eighteenth century. The extent to which their powers became limited in this period becomes apparent by comparing fifteenth- and sixteenth-century Central Asia Islamic notary manuals with those written in the nineteenth century. ${ }^{48}$ While the former point to the fact that a substantial share of $q \bar{a}$ dìs's output consisted of sijills, the latter clearly indicate that sijills were requested only in cases of animal theft. Notary manuals show

46 The Central Asian sijill did not include the witnessed record of the contents of a claim as in earlier periods, but only the ruling; cf. W.B. Hallaq, "The Qāḍ̂̀s Dīwān (Sijill) before the Ottomans." BSOAS 61/3 (1998): 420; M.K. Masud, R. Peters, and D.S. Powers, "Qādīis and Their Courts: An Historical Survey": 21. For an insightful discussion of record-keeping practices of Ottoman $q \bar{a} \mathfrak{d} \bar{\imath} s$, see G. Burak, "Evidentiary Truth Claims, Imperial Registers, and the Ottoman Archive: Contending Legal Views of Archival and Record-Keeping Practices in Ottoman Greater Syria (Seventeenth-Nineteenth Centuries)." BSOAS 79/2 (2016): 233-54.

47 We know of four $q \bar{a}$ ḍ $\bar{\imath}$ registers that were produced in Khiva between 1893 and 1912, that is, during the period of the Russian protectorate. Their composition, however, was probably prompted by new bureaucratic norms introduced by the Russians, which regulated record-keeping practices and would facilitate communication between the Khivan chancellery and the governor of the Amu-Darya Department based in Petroaleksandrovsk; see A. Shaikhova, "O Khivinskoi kaziiskoi knige iz fondov Instituta vostokovedeniia An UzSSR." ONU 6/8 (1982): 53-57. Catalogues of Central Asian Islamic legal documents usually render sijill as "register," which is misleading. See A. Urunbaev, G. Dzhuraeva, and S. Gulomov, Katalog sredneaziatskikh zhalovannykh gramot iz fonda Instituta vostokovedeniia im. Abu Raikhana Beruni Akademii Nauk Respubliki Uzbekistan (Halle/Saale: Orientwissenschaftliches Zentrum der Martin-Luther-Universität Halle-Wittenberg, 2007): doc. 18, 22, 23, 68, 69; T. Welsford and N. Tashev, A Catalogue of Arabic-Script Documents from the Samarqand Museum (Samarkand and Istanbul: IICAS, 2012): docs. 422,423 .

48 For an important specimen of a fifteenth-century Islamic notary manual, see Ikhtiyār al-Dīn b. Ghiyāth al-Dīn al-Ḥusaynī, Mukhtār al-ikhtiyār 'alā al-madhhab al-mukhtār, Ms Bodleian, Frazer 235: fol. 16a and passim. For early sixteenth-century material, see 'Alī b. Muḥammad-'Alī b. 'Alī b. Maḥmūd al-Mukhtārī al-Khwārazmī al-Kubrawī, al-Jawāmi' al-'alīya fì al-wathā̉iq al-shar'ìya wa al-sijillāt al-mar'ìya, Ms Tashkent, TsVRUz, no. 9138. On this manuscript and its author, see Subtelny, Timurids in Transition: 222. 
that $q \bar{a} d \bar{l} \bar{s}$ crafted only two types of sijills. One such document (pusht-imahdar sijill ${ }^{49} /$ sijill-i ashtār, asb wa murakkab ${ }^{50} /$ wathiqqa-yi khatt-i sijill-asb ${ }^{51}$ ) was given to claimants to solemnize the recovery of their property. ${ }^{52}$ The respondents, too, had a potential interest in receiving a sjill in order to be able to claim later the restitution of the money from the individual who had sold him the stolen animal. This type of sjill was called qahqarī. ${ }^{33}$ That juristic manuals lithographed in Bukhara included these two types of sijills only ${ }^{54}$ is further evidence of the fact that, in the nineteenth century, qā dīs probably issued rulings mostly on such cases. Does this mean that $q \bar{a} d \bar{\imath}$ s heard only cases involving animal theft? Or that animal theft was the most common among the cases heard by $q \bar{a} d \bar{i} s$ ? There is no way to answer these questions, but the fact that notary manuals did not include the templates for other types of rulings suggests that

49 Majmū'a-yi wathāì wa murāsalāt, ms Tashkent, TsVRUz, no. 8958: fol. 15a-b (early twentieth century). The expression pusht-i mahdar sijill refers to the fact that a plaintiff could acquire a sijill notarized on the verso side of a protocol of claim. For one such common practice, see TsGARUz, f. R-2678, op. 2, d. 9o, l. 1-1ob, which refers to a case of recovery of property consisting of one horse by a certain Muhammad Sa'īd Khwāja in Nasaf (present-day Qarshi) in 1884.

Munsha'āt-i Mirzā Bahādir Khwāja b. Husayn Khwāja Pìrmastī, ms Tashkent, TsVRUz, no. 2667: fol. 86b-87a (early twentieth century).

$5^{1}$ Wathä'iq-i mutafarraqa, Ms Tashkent, TsVRUz, no. 6057/1: fol. 5a (mid-nineteenth century); Wathā'iq, Ms Tashkent, TsVRUz, no. 4594/II: fol. 44a-b (late nineteenth century); Wathäiq, Ms Tashkent, TsVRUz, no. 8072: fol. 1 b. For the Chaghatay translation of a model document (sijill khatț nuskhasī), see Majmū'a-yi wathā̉iq, MS Tashkent, TsVRUz 7799: fol. 53a-55a (early twentieth century, Khazarasp, Khorezm oasis).

$5^{2}$ I have discussed the stipulations of such documentary forms in "The Birth of a Custom: Nomads, Sharīa Courts and Established Practices in the Tashkent Province, ca. 18681919." ILS 18/4 (2011): 319.

53 Majmūa'a-yi wathā̉iq wa murāsalät, ms Tashkent, TsVRUz, no. 8958: fol. 15b (here wathīqa-yi qahqarī); Munsha’āt-i Mirzā Bahādir Khwāja b. Husayn Khwāja Pōrmastī, Ms Tashkent, TsVRUz, no. 2667: fol. 87b (here sijill-i qahqarā-yi asb wa ashtar wa murakkab); Wathāiq-i mutafarraqa, Ms Tashkent, TsVRUz, no. 6057/1: fol. ${ }_{5} \mathrm{~b}$ (here wathiqqa-yi khatț-i sijill); Wathä̀iq, Ms Tashkent, TsVRUz, no. 4594/II, fol. 44b-45a (here wathīqa-yi qahqarì); idem, in Wathäiq, Ms Tashkent, TsVRUz, no. 8072, fol. 5a; Formuliarnik iuridicheskikh dokumentatsii XX v. na tadzhikskom iazyke, arabskim grafikom [1910 g.], TsGARUz, R-2678, op. 2, d. 244, l. 10a (here sijill-i qahqarī). See the Chaghatay translation of the same type of document (khattt-i qahqarīning nuskhasī) in Majmü'a-yi wathä’iq, Ms Tashkent, TsVRUz 7799 , fol. $56 \mathrm{~b}-58 \mathrm{~b}$.

54 Naẓrallāh Bāy b. Qāyil Bāy and Mullā Sulțān b. Mullā Șābir, Jung-i fatāwā wa maḥ̣arāt (Bukhara: 1325/1907-8): 473-474 (here, respectively, sijill-i awwal and sijill-qahqarì). 
$q \bar{a} d \bar{l}$ s did not need to keep sight of such templates because they issued most probably such records only rarely. 55

Without the vested interests of the disputants, where else could one find traces of the judicial activities of the $q \bar{a} d \bar{l} \bar{s}$ ? Most of the records that are usually termed "qadi documents" are actually texts that belong to private collections. Parties to disputes did not acquire texts reflecting the process of adjudication, unless they might prove useful for the substantiation of some future claim. If we exclude the few sijills I mentioned, evidence of sharía courts resolving disputes would be feeble at best. Indeed, the limitations to qä $\overline{l i s}^{\prime}$ judicial powers become even more apparent when one realizes that their actual role in conflict resolution amounted mostly to the notarization of amicable settlements (șulh). ${ }^{56}$ More often than not, settlements were reached with the mediation of a third party, usually local notables, who decided also the stipulations of the agreements.

If $q \bar{a} d \bar{l} \bar{s}$ and other judicial personnel left behind little evidence of judicial activities, it probably means that we have to look beyond the judges for attestations of instances of conflict resolution and records of the implementation of sharīa.

From the end of the eighteenth century, we begin to find evidence of a process of bureaucratization and centralization of the Islamic legal system. The Manghit ruler Shāh Murād (r. 1785-1800) appears to have been the first ruler to set this process in motion. The richest account of such "legal reforms" comes from a Bukharan court chronicler, Mīrzā 'Abd al-Aẓīm Sāmī. In his "Royal Gift," a chronicle with which he intended to exalt the accomplishments of the Manghit dynasty, Sāmī wrote:

The royal court [bār-i mulukāna-yi dawlat], which had been maintained since the times of Chingīz Khān, was dissolved; in lieu thereof, he [the

TsVRUz Khiva qozilik khujjatlari (Aklia Aliakbarova's collection), docs. 16a 71, 583, 645, 675, 685 refer to disputes over property rights on land and water that occurred in Khorezm in the second half of the nineteenth and early twentieth century.

$5^{6}$ Indeed, there are many certificates of acquittal $\left(i b r \bar{a}^{\prime}\right)$ in such private collections. These records too may refer to the outcome of a dispute. When parties agreed on a settlement, shari $a$ courts usually notarized certificates that solemnized the stipulations of the amicable settlement, but we also encounter the opposite case. That is, certificates of acquittal could be produced following conflicts that were settled outside of the court; see my "Murder in Manghishlaq: Notes on an Instance of Application of Qazaq Customary Law in Khiva." DI 88/2 (2012): 217-57. We also observe cases in which such records were purposely crafted in the absence of disputes, in order to deter adversaries from taking legal action. 
emir] established the tribunal of justice [mahkama-yi 'adālat]. Forming an assembly along with forty ' ulama', he heard the petitions of the people ['arāyid-i mardum rā pursìda] and, in the presence of the scholars, made decisions according to the religious law. Holding this assembly mostly on Fridays and Mondays, he gave no credence to the word of the claimant until the defendant appeared [tā mudda'a 'alayh hạdir nashawad qawl-i mudda $\bar{\imath}$ rā itibār nakardī]. There was no help for anyone to escape the justice of his tribunal: the mean and the noble, chiefs and poor people, all were equal before this rule. Even the [most miserable] servant could drag his master before this court of justice [banda mì tawānist khwāja-yi khwud rā dar mahkama-yi 'adālat ba murāfa'a kashad].57

We learn from this stylized representation that Shāh Murād presided over a tribunal of justice in which people filed their claims by means of petitions. It might be objected that this excerpt is reminiscent of the mirror-for-princes genre. It is true that works belonging to this genre conventionally cite "justice" ('adälat) as the attribute that Muslim rulers should possess in order to govern the country and ensure stability; ${ }^{58}$ Central Asian works are no exception in this respect. Several sources from that period praise the reign of Shāh Murād as one under which shari ${ }^{-} a$ prospered ${ }^{59}$ but I see little reason to consider mirrors for princes, treatises on kingship in general, and court historiography as sources providing only models, unreflective of social reality. ${ }^{60}$ If these genres insist that the ruler should possess the attributes of the just person, it was precisely because it was common knowledge that a ruler should hear cases and be involved in the

57 Mīrzā 'Abd al-'Aẓ̄im Būstānī [Sāmī], Tuhfa-yi shāhī, ed. N. Jalālī (Tehran: Anjuman-i Āthār wa Mafāhir-i Farhangī, 1388sh/2010): 53

$5^{8}$ A.S. Lambton, "Justice in the Medieval Persian Theory of Government." Studia Islamica 5 (1956): 91-119; eadem, "Islamic Mirror for Princes." In Atti del covegno internazionale sul tema, La Persia nel Medioevo (Roma, 31 marzo-5 aprile 1970) (Rome: Accademia Nazionale dei Lincei, 1971): 419-42; M.E. Subtelny, "A Late Medieval Persian Summa on Ethic: Kashifi's Akhlāq-i Muhsinī." Is 36/4 (2003): 601-14.

59 O.D. Chekhovich, "K istorii Uzbekistana v XVIII v." In Trudy Instituta Vostokovedeniia 3 (1954): 62; A. von Kügelgen, Die Legitimierung der mittelasiatischen Mangitendynastie in den Werken ihrer Historiker, 18.-19. Jahrhundert (Istanbul: Ergon, 2002): 285.

6o I am here taking a position that differs from R.P. Mottahedeh, Loyalty and Leadership in an Early Islamic Society, 2d ed. (London and New York: I.B. Tauris, 2001): ix. For a position close to mine, see Y. Karev, "From Tents to City. The Royal Court of the Western Qarakhanids between Bukhara and Samarqand." In Turko-Mongol Rulers, Cities and City Life, ed. D. Durand-Guédy (Leiden: Brill, 2013): 124. 
adjudication of disputes: 61 "If we do not appeal to the ruler [in cases regarding] blood money, water [rights, cases of] injustice, and other matters, then what is the emir good for?," wrote the nineteenth-century Bukharan polymath Ahmad Dānish in reflecting on the duties of the Manghit emirs. ${ }^{62}$

The passage I quoted from Sāmī suggests that, before Manghit rule, the royal courts of Transoxiana provided some kind of legal service; to represent the latter as a survival of Chinggisid political tradition, however, is obviously an authorial action taken by Sāmī to sketch pre-Manghit legal practices in disparaging terms in order to magnify his master. It is also be possible that Shāh Murād was not the great innovator that Sāmī wants us to think. There are several precedents in the early-modern history of the Persianate world in which people could bring their complaints to the royal courts of Muslim principalities, such as those of Shāh 'Abbās (r. 1588-1629) ${ }^{63}$ and Sulțān Ḥusayn Bāyqarā in Herat (r. 1469-1506). ${ }^{64}$

But nineteenth-century sources allow us to describe more than mere compositional conventions on men of government inhabiting the ideal type of the just ruler. Local chronicles, for example, offer vivid accounts of Central Asian rulers touring their domains to hear the grievances of their subjects- the dispensation of justice by peripatetic rulers:

During the entire expedition his majesty entertained himself with various kinds of falconry and hunting and, at the same time, would inquire

61 M. Alam, "Shari'a and Governance in the Indo-Islamic Context." In Beyond Turk and Hindu: Rethinking Religious Identities in Islamicate South Asia, ed. D. Gilmartin and B.B. Lawrence (Gainesville, FL: University Press of Florida, 2000): 220.

62 agar mā az wajh-i khūn wa āb wa sitam [wa] ghayr ba-sulțān 'ard na-kunim ba-mā amìr ba-cha muhimm ba-kār ast?, Aḥmad Makhdūm Muhandis-i Bukhārī, alias Aḥmad-i Kalla, Tarjimat al-aḥwāl-i amīrān-i Bukhārā-yi sharīf, Ms Tashkent, TsVRUz, no. 1987: fol. 54b. "Blood money" (khūn) denotes a restitutional payment, rather than a punitive one.

63 R. Matthee, “Was Safavid Iran an Empire?” JEsHo 53/1-2 (2010): 247.

64 Niẓām al-Dīn 'Abd al-Wāsi` Niẓāmī [Bakharzī], Manshā’ al-Inshā’, comp. Abū al-Qāsim Shihāb al-Dīn Ahamd Khwāfì, ed. Rukn al-Dīn Ḥumāyūnfarrukh, vol. 1 (Tehran:Intishārāt-i dānishgāh-i millī-yi İrān, 1357sh/1978): 212, which includes a copy of a diploma appointing Khwāja Majd al-Dīn Muhammad Khwāfì to the office of parwāna. The appointee was expected to report to the sultan (ba mawqif 'ard rasānīda) every kind of petition (har $n a w^{c}-i$ 'arida-dāsht), including legal disputes (qad̄ayāa $i$ shar $\bar{\imath}$ ) or incidents related to custom (waqāyi $-i$ ' $u r f i$ ), and reply in written form. As we shall see, this workflow is similar to what is reflected in nineteenth- and early-twentieth-century sources. My reading here differs substantially from that of Subtelny, Timurids in Transition: 84 fn. 48 . 
every day about the affairs of the subjects and the poor, catching their hearts, like game, with the falcon of his kindness. ${ }^{65}$

At times he ['Abd al-Ahad] went to the provinces of Qarshi and Shahrisabz to hear the petitions of the people ['arāyid-ifuqarā]. ${ }^{66}$

It might be objected that these are not vivid accounts of the dispensation of justice, given that such vignettes appear in poetry and paintings [Fig. 3] and thus may be read as compositional motifs. ${ }^{67}$

However, because it has been established that court chroniclers made extensive use of archival records, ${ }^{68}$ it would make little sense to regard chronicles as less authoritative than legal records, the more so because there are several travelogues that refer to Central Asian rulers holding public audiences to hear their subjects' claims:

The people who are in charge of the dispensation of justice [sudoproizvodstvo] in the khanate [of Khiva] are those at the head of the

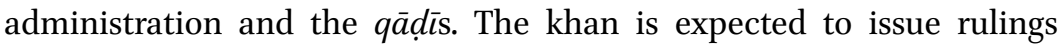
publicly to those who address him with an appeal $[$ arz $] .{ }^{69}$

Every day, around two o'clock, [the khan] goes to court to hear cases and complaints [razbirat' dela i zhaloby]. In summer quarters, court is held right in the courtyard, in which are arranged earthen couches; the khan

65 Shir Muhammad Mirab Munis and Muhammad Riza Mirab Agahi, Firdaws al-Iqbal (History of Khorezm), trans. Y. Bregel (Leiden: Brill, 1999): 456-7.

66 Mīrzā 'Abd al-'Aẓ̇̄m Sāmī, Ta’rīkh-i salāțīn-i manghitīya (Istoriia Mangytskikh gosudarei), ed. L.M. Epifanova (Moscow: Izdatel'stvo vostochnoi literatury, 1962): 109a.

67 On the relationship between hunting and justice in the Mughal period, see E. Koch, DaraShikoh Shooting Nilgai: Hunt and Landscape in Mughal Painting (Washington, DC: Freer Gallery of Art, Arthur M. Sackler Gallery, Smithsonian Institution, 1998).

68 Muhạmmad Rị̣ā Mīrāb Āgahī, Jāmi` al-wāqi'āat-i sulțānī, ed. N. Tashev (Samarkand and Tashkent: IICAS, 2012): xx; Fayḍ Muhammad Kātib Hazārah, The History of Afghanistan: Fayz Muḥammad Kātib Hazārah's Sirāj al-tawārīkh, vol. 1, The Sādūzā̄̄ Era 1747-1843, trans. and ed. R.D. McChesney (Leiden: Brill, 2013): xciii-xcv.

69 “Iz knigi V.I.Mezhova 'Khivinskii pokhod 1873 g.' s izlozheniem svedenii o khivinskom khanstve v administrativnom i voennom ustroistve." In S.K. Kamalov, Khoziaistvo karakalpakov XIX v., MS Nukus, FBKOANRUz, no. R-go: [6]. The author of this text was not Mezhov. This text does not correspond to "Khivinskii pokhod v 1873 godu (po ofitsiial'nym istochnikam)." Voennyi Sbornik 1873 (1911), which figures among the works of S.K. Kamalov, Karakalpaki v XVIII-XIX vekakh: K istorii vzaimootnoshenii s Rossiei i sredneaziatskimi khanstvami (Tashkent: Fan, 1968). 


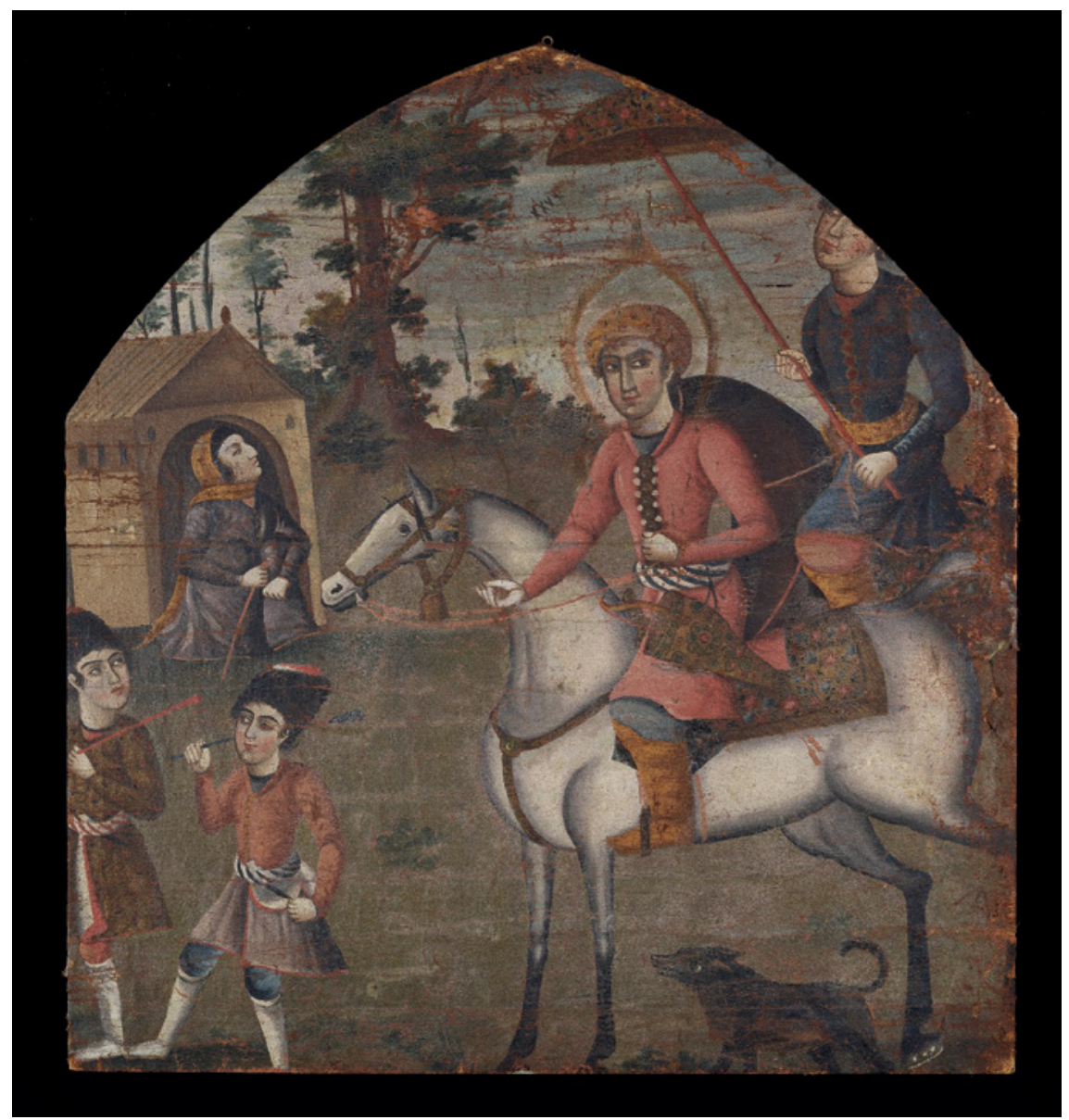

FIGURE 3 Sultan Sanjar and the Old Woman, mid-18th century. Oil on canvas, $36 \times 35$ in. $(91.4 \times 88.9 \mathrm{~cm})$. Brooklyn Museum, Bequest of Irma B. Wilkinson in memory of her husband, Charles K. Wilkinson, 1997.108.4.

sits on one of these, on a velvet pillow, leaning on his hand for greater comfort, and hears complaints. ${ }^{70}$

$70 \quad$ "Seid-Mukhamed-Rakhim, khivinskii khan, i ego priblizhenie." Vsemirnaia illustratsiia n. 243, reprinted in TS 42 (1873): 120. Also, a vivid account of the Bukharan emir hearing the grievances of his subjects can be found in Zapiski o Bukharskom khanstve (Otchety P.I. Demezona I I.V. Vitkevicha), trans. V.G. Volvnikov and Z.A. Tsomartova (Moscow: Nauka, 1893): 51 . 
As at this hour there were almost every day an Arz (public audience), the principal entrance, as well as the other chambers of the royal residence traversed by us, were crowded with petitioners of every class, sex, and age. They were attired in their ordinary dresses, and many women had even children in their arms, waiting to obtain a hearing; for no one is required to inscribe his name, and he who has managed to force his way first is first admitted. ${ }^{71}$

One of the most vivid accounts of the procedure of petitioning the ruler in Khiva comes from the Russian officer and Orientalist Nil Sergeevich Lykoshin. When, in 1912, he drafted this description, Lykoshin was the head of the AmuDarya Department and thus a man endowed with privileged knowledge about the functioning of the legal system in the country:

About six o'clock in the evening, the usually deserted courtyard, decorated with tall columns in the Moorish style, suddenly perked up.... Sometime later, the harem door opened, whence Isfandiyār Khān Bahādur proceeded to the place where he sits to mete out judgment and punishment. Not far from the only entrance into the courtyard there is a small stone platform, covered with a large felt mat. The khan sits on the dais in Asian style, and before him they lay out an ancient gun in its case and a small hatchet, also old; these are the insignia of power. The khan wears an expensive gold-trimmed saber of the Asian type, and on his head, in place of the usual fur hat, he has an equally large hat of lamb fur, but with a red top; this hat is the equivalent of a crown. By the khan's hand they place a kettle of green tea and a cup. Even before the khan's entrance, a mahram ${ }^{72}$ takes up a position not far from the khan's dais and stands perfectly still, with his head bare. From time to time, these mahrams are silently replaced by others newly entered into the courtyard. The old man Yūsuf Yasāwulbāshī begins the ceremony.... The time for parsing the people's complaints has come....

71 A. Vámbéry, Travels in Central Asia: Being an Account of a Journey from Teheran across the Turkoman Desert of the Eastern Shore of the Caspian to Khiva, Bokhara, and Samarcand (London: John Murray, 1864): 126-7.

72 A mahram was a proxy for the khan who carried out his personal instructions. According to Tarrāh, among the numerous mahrams who served at court, a special position was occupied by the so-called 'ard-khāna mahramlarī, who were responsible for preparing the reception room for the daily ceremony and were at the khan's disposal for its duration; see Bobojon Tarroh-Khodim, Khorazm shoir va navozandalari, ed. A. Otamurodova and O. Abdurahimov (Toshkent: Tafakkur qanoti, 2011): 30 . 
The khan's subjects complain to him about each other and ask for the restoration of rights violated by others of his subjects. The petitioner, having entered through the door, stops at the entrance, quite far from the khan, so his complaint is pronounced in a very loud voice, the supplicant almost yelling, as if he hopes to prove the severity of his grievances and to penetrate the soul of the khan with his cries. The khan, having allowed the supplicant to finish his brief complaint, says only one word, turning to the Yasāwulbāshī. This is probably an order to sort out the case. The petitioner exits, another enters. ${ }^{73}$

The involvement of the royal court in the local populace's petty disputes is best illustrated in the paper trail produced by the Manghit and the Qunghrat chancelleries. The records preserved by the agencies in Bukhara and Khiva show that individuals who wanted to take legal action against others had to come first to the gates of the citadel (ba-darwāza-yi ark-i 'âlı àmada) and submit an appeal (ba-'ardi-i 'âlì rasānìd). If the appeal was accepted, the royal court instructed an officeholder to deal with the case. That is, only a small fraction of the disputes filed with the royal court were actually heard by the ruler and resolved by him: sultanic justice was usually administered by someone authorized by the ruler to do so.

In Central Asia, appeals ('ard, lit., "petition") were not submitted in writing. Taking legal action before the royal court was an oral procedure. To be sure, however, no one forbade appellants from providing additional textual support, which usually took the form of a protocol of claim (mahdar). Mahdars were usually compiled by jurists' scribes (muharrir) and bore the seal of a mufti for which the applicant paid a fee (muhrāna).${ }^{74}$ Such texts served the specific purpose of translating a complaint into a full-fledged legal case. They thus consisted of a brief description of the offense, a claim $\left(d a^{c} w \bar{a}\right)$, and a request for redress. They also included a quotation from texts of substantive law (furü al-figh), which served as precedents to show how the case referred to a specific point of law on which Islamic scholars had already ruled. Such texts were

73 N.S. Lykoshin, Zapiska Amu-Dar'inskogo otdela Polkovnika Lykoshina o sovremennom sostoianii Khivinskogo khanstva, 1912 god, TsGARUz, f. I-2 op. 1 d. 314, ll. 15-16 ob.

74 The structure and formulas typical of the protocol of claims have been studied preliminarily by K. Isogay, "Seven Fatwa Documents from Early 2oth-Century Samarqand: The Function of the Mufti in the Judicial Proceedings Adopted at Central Asian Islamic Court." Annals of Japan Association for Middle East Studies 27 (2011): 259-82. On the basis of a collection of protocol of complaints and fatwas, Isogay attempts to reconstruct the adjudication procedure. He infers that, before colonization, plaintiffs filed their claims with the $q \bar{a} d \bar{\imath}$ by providing a protocol of claim. In the present study, I suggest that this was not the case, because mahdars were, more often than not, presented to the royal court. 
encoded in vernacular legalese and peppered with Islamic legal formulae, and they left little room for the claimant's voice.

\subsection{The Royal Court}

The royal court usually opted for a resolution of the conflict without recourse to adjudication by the qā $\bar{c} \bar{\imath}$. As the correspondence between the khans and their attendants shows, the prime concern of the royal court was to streamline the provision of reparation of an offense. The royal court was, however, aware of the possibility that defendants might object to the solution offered to them. The court therefore instructed its addressees that, if the defendants denied the claim, the case should be passed to a qā $\bar{\imath} \bar{\imath}$ for adjudication.

In the following example, Emir Haydar (r. 1800-26) addresses a letter (maktūb) to a local governor, instructing him to deal with the case directly, unless the parties to the dispute request the application of the adjudication's procedure:

Let the refuge of glory, the repository of the emirate, and the choice of the khans, Muhammad Hakìm Bī Mihtar, know that [some] villagers [ fuqarā] have assaulted and dishonored a certain 'Ālim Bābā. The aforementioned [parties] must be summoned and the honor taken [from 'Ālim Bābā] be restored. Should they respond in legal terms [agar ānhā harf-i shar ' güyand], they must be referred to the qădì, who will hear the conflict between the parties [mudda'i mudda'ā 'alayh muräfa'a kunand]. Let be peace upon you $7^{75}$

This is how Emir Haydar reacted to the cases brought before him. Other Bukharan rulers proceeded in a similar fashion. Emir Nașrallah (r. 1827-6o), for example, instructed Bī Muhammad Ḥakīm Bī Kul Qūshbīgī to deal with a case of insolvency in the following way:

Let the refuge of the vizirate, the repository of the emirate, a man of noble rank and position, Bī Muhammad Ḥakīm Bī Kul Qūshbīgī, know that a certain Qurbān Bāy, an Arab, is debtor [qarḍdār] of Khān Bahādur Afghān. Although he owns a plot of land, as reflected in a deed, he does not want to exchange it for a just price in order to resolve a debt. You must summon him and look into the matter [bāyad ki hạdir karda binīid]. Should it really be as reported, you must have his land handed over to 
the proxy, Mullā Dhū al-Fiqār, for its just price. Should [he respond] in legal terms, you have to support the law [agar harf-i shari wäqi' shawad hämīyi shar' shawìd]. ${ }^{76}$

It is striking that, in the two passages above, the individuals asked to resolve disputes did not hold judicial office. Emir Haydar wrote to his mihtar, while Nașrallah involved the qūshbigi $\overline{.}^{77}$ Under the rule of Emir Muzaffar, appeals were frequently transmitted to Sayyid Mīrak, who held the office of yasāwul-i ulam $\bar{a}$. Such appeals included all sorts of claims under both criminal and civil law. We read, for instance, that, one day in Muharram 1282/May-June 1865, Sayyid Mīrak was informed by the royal court that a certain Qurbān Bāy had committed a double homicide. He had killed his wife and his younger brother after he had seen them engaged in illicit intercourse (kār-i nā-mashrū $)$. The woman's mother, together with other trustworthy individuals (ädamān-i khäliș), offered a different version of the case. They said that the two men had argued on their way home and on that occasion Qurbān Bāy killed his brother; then he moved on to his home and murdered his wife. The royal court thus instructed Sayyid Mīrak to make an inquiry, ascertain the truth, and report back. He was further instructed that, if the yasāwul-i 'ulamā' established that Qurbān Bāy had indeed killed the two because he had seen them during illicit intercourse, Sayyid Mirak should resolve the case by enforcing the payment of blood money, which, we may infer, would lead to the notarization of a contract of peaceful settlement. If the circumstances of the murder were different, the yasāwul-i 'ulamāa was expected to proceed instead according to the adjudication procedures. ${ }^{78}$ This was a case of homicide. Sayyid Mīrak was

76 Majmūáa-yi maktūbāt-i Sayyid Amìr Nașrallah Bahādur Khān ba Muhammad Hakīm Bī Kul Qūshbīgì, Ms Tashkent, TsVRUz, no. 1998: fol. 131b (maktūb 441).

77 On the office of qüshbigì, see W. Holzwarth, "The Uzbek State as Reflected in Eighteenth Century Bukharan Sources." Asiatische Studien 6o/2 (2006): 334-5.

78 bāyad ki taḥqūq karda haqū̄qat-i ū rā dānista 'arḍ kunīd ki agar ba-kār-i nā-mashrū' dìda qațl karda bāshad khūnash hadr mīshawad wa illā muwäfiq-i shar'i sharïf ba-qaț mìrasad, Maktūbāt-i Amīr Muzaffar ba-Sayyid Mīrak wa 'arāyiḍ-i Sayyid Mīrak, MS Tashkent, TsVRUz, no. 1740: fol. 32a [sic! 23a] (Oriental pagination), doc. 432. The manuscript has been described in Sobranie vostochnykh rukopisei Akademii Nauk Uzbekistan. Istoriia, ed. D.Iu. Iusupov and R.P. Dzhalilov (Tashkent: Fan, 1998): 411-12. The instructions bāyad ki tahquīq karda haquīqat-i ù rā dānista 'ard kunīd are doubtless formulaic expressions employed also in the instructions that the royal court sent to the judges. 
usually instructed to resolve more mundane cases, such as the usurpation of waqf properties $^{79}$ or matters concerning guardianship. ${ }^{80}$

Read literally, these instructions suggest that the royal court functioned as a court of equity, that is, a legal venue that resolved conflicts by avoiding the more formalistic system of adjudication followed by the $q \bar{a} d \bar{\imath} \mathrm{s}$. As we have seen in the preceding section, the royal court either resolved disputes directly during hearings presided over by the ruler or directed parties to the authority that would resolve them. Indeed, the royal court often instructed its attendants to refer the parties to the qādīs in case of the denial (inkār) of a claim. The royal court's representatives (attendants, governors, notables) and the qā sented a sort of dualism: the former was a quicker way to achieve the resolution of a conflict; the latter was a more elaborate procedure of adjudication. It would be wrong, however, to suggest that they represented a case of legal diversity. Certainly, it was not so in the eyes of those who sought redress at the royal court, because the court did not follow a law different from sharita. This is best reflected in those cases in which the royal court transferred to qā resolution of claims that were filed directly with the royal court. It is to these cases that we now turn.

\subsection{Qāḍīs as Prosecutors}

The procedure of appeal to the royal court could lead to the involvement of members of the judicial body. Judges, regardless of their rank, were often assigned to hear a case only following the royal court's agreement to make inquiry into an appeal. ${ }^{81}$ As in the case of Sayyid Mirrak, the royal court advised the judges on how to deal with lawsuits-for example, by suggesting the enforcement of restitution of money or the prohibition of slander. ${ }^{82}$ In Bukharan bureaucratese,

79 Maktūbāt-i Amìr Muzaffar ba-Sayyid Mīrak wa 'arāyị̣-i Sayyid Mīrak, Ms Tashkent, TsVRUz, no. 1740: fol. 23b, doc. 438 .

8 o Ibid.: fol. 25 b, doc. 471 .

81 See the royal warrants addressed to the chief judge (qāḍ̂ kalān) Mullā Mīr Șadr al-Dīn, AMIKINUz, untitled collection of Arabic-script documents: collection series no. 396a and 398. Cf. Welsford and Tashev, A Catalogue of Arabic-Script Documents from the Samarqand Museum: doc. 190, 197. The biography of Mullā Mīr Șadr al-Dīn, "one of the most influential figures in the Bukharan legal establishment from the early 1860 s until the early 1880 s," is outlined in ibid.: doc. 85 , fn. 2.

82 AMIKINUz, untitled collection of Arabic-script documents: collection series no. 396a: wāqi'an chunīn bāshad ḥaqīqat-i ù rā tahqūq karda dānista tanga-yi māndagī-yi ù rā girifta dāda; 398: ma'lūm shawad bāyad ki tahquīq karda [text damaged] man' namūda 'ār-i ù rā [text damaged]. 
such instructions were referred to as $a m r-i$ ' $a \bar{l} \bar{l}$, that is, a direction delivered by the royal court, with which the appointees, regardless of their office, were obviously expected to comply. The communication of such a command to the office holder followed the procedures of a public ceremonial in which the royal warrant was entrusted to the recipient. The latter would, as in the case of the diploma of appointment, kiss it, rub it on his eyes, and wear it in his turban (tabarruk-nāma-yi kirāmī rā būsīda ba-chashmānam mālēda tāj-i sar namūda). He would literally "wear it as a crown around its head." This procedure applied also to the qadis when, as we shall see, they were instructed to adjudicate a case, and it symbolized clearly that the recipient greatly esteemed being entrusted such an order. ${ }^{83}$ The following example illustrates in detail such a procedure and situates it in a specific legal case. It shows how women could take legal action by appealing directly to the ruler and how $q \bar{a}$ dis proceeded in the manner of a prosecutor, according to the instructions of the royal court.

A certain Tūy Bībī from Ūstīis appealed and let us know ['arḍ-i 'àlī] that Sulțān Murād and Jum‘a Bāy, who are wicked men, together with Shāh Naẓar, Hūr Bībī, and Nūr Sulțān, attacked her integrity, assaulted her, and caused her much distress. [You ordered me] to look [into this matter] and, if this is what happened, to restore her honor. In case [the defendants object], [you advised me] to hear the case. Oh, you, seat of the world, [let it be known that] this supplicant who strives to please [you] took the royal warrant with his two hands of politeness, kissed it, and rubbed it on his eyes. I summoned Sulțān Murād and Jum'a Bāy to the bazaar of Khwāja Kanfi and questioned them. They said that they did not assault the woman and denied [ munkir] the claim. The impartial local notables [āqsaqua $l \bar{a} n^{85}$ wa kadkhudāyān-i khäliș] intervened and prayed endlessly for my great Lord and said that Sulțān Murād and Jum'a Bāy brought a royal warrant

\footnotetext{
83 TsGARUz, f. I-126, op. 1, d. 2o, ll. 47, 91; I-126, op. 1, d. 22, l. 58.

84 It is unclear whether "Ūstī" refers here to a settlement (mawdi $i$ ) or a province (wilāyat) southwest of Bukhara; see Naselennye punkty Bukharskogo émirata (konets XIX-nach. XXvv.). Materialy $k$ istoricheskoi geografii Srednei Azii, ed. A.R. Mukhamedzhanov (Tashkent: Universitet, 2001): s.v.

85 For the position of āqsaqual, see A. Wilde, "Creating the Façade of a Despotic State: On Āqsaqāls in Late 19th-Century Bukhara." In Explorations in the Social History of Modern Central Asia (19th-Early 2oth Century), ed. P. Sartori (Leiden: Brill, 2013): 267-98.
} 
showing that they had filed a claim for their rights of inheritance against Tūy Bībī. For this reason, they had a controversy over self-interest. They [the local notables] took 800 tangas from Tūy Bībì and gave them to Sulțān Murād and Jum'a Bāy. The latter stated that they withdrew their claim on the inheritance and gave a certificate [wathīqa] to Tūy Bībì. The woman, too, said that she relinquished her claim for slander and entrusted to the two men a certificate of complete discharge of obligation [khatț-i wathiqa-yi ibra'-i 'ämm]. The parties reconciled, and [the dispute] was resolved. ${ }^{86}$

Looking at the case of Tūy Bībī has, I hope, clarified the marginal role played by the $q \bar{a} d \bar{l} \bar{i}$ in the resolution of disputes. He no doubt acted on behalf of the state, when the emir instructed him to look into a conflict, but, as soon as the defendants denied the accusation, an action that would have made the production of evidence incumbent on the claimant, a third party intervened and arranged an amicable settlement. ${ }^{87}$ In the resolution of the conflict, the $q \bar{a} d \vec{\imath}$ s role was thus confined to that of a notary: he solemnized the discharge of obligations on each side and reported the settlement to the ruler. ${ }^{88}$

Having established that, in the sharita field in nineteenth-century Bukhara, the judicial personnel often acted at the instigation of the ruling house, we should note that, in certain cases, parties to a dispute referred to $q \bar{a}$ di $\bar{i}$ of their own volition and that, in doing so, they were presumably not appealing to the emir. Sporadically, we find petitions to the ruler in Bukhara or his closest acolytes in which we can discern that complainants approached a $q \bar{a} d \bar{\imath}$, prayed for the well-being of the emir, and filed directly with the judge a claim against suspects. ${ }^{89}$

In these cases too, however, qädīs appear not to have had a monopoly on Islamic justice nor to have acted independently within their own territorial

86 Judicial report ('ariza-dāsht) to the emir, n.d., TsGARUz, f. I-126, op. 1, d. 1761, l. 3. Stamp of a Bukharan qā

87 I have illustrated at length this procedure of mediation in my "The Evolution of ThirdParty Mediation in Sharī $a$ Courts in 19th- and Early 2oth-Century Central Asia." JESHO 54/3 (2011): 311-2.

88 For dozens of such cases, see TsGARUz, f. I-126, op. 1, d. 1761-65.

89 TsGARUz, f. I-126, op. 1, d. 1762, l. 15: report addressed by Qāḍī Mullā Fayḍullāh Khwāja to the emir (undated and unstamped); TsGARUz, f. I-126, op. 1, d. 1762, l. 21: report addressed by Qāḍī Mullā Sadallāh Șudūr to the emir of Bukhara (undated and unstamped); TsGARUz, f. I-126, op. 1, d. 1762, l. 23: report addressed by Qāḍī Mullā Imānallah Khwāja to the emir (undated and unstamped); TsGARUz, f. I-126, op. 1, d. 1762, l. 24: report addressed by Qāḍī Mullā Mīr Qudratallāh Ra'is to the emir (undated and unstamped). 
jurisdiction. From the nature of their correspondence with the administrative center of the emirate, it appears that $q \bar{a} d \bar{i}$ s took pains to provide regular reports of what they did. Individuals holding the official post of judge were held accountable for the way they conducted preliminary investigations and for the way they performed adjudication in their court. In sum, every step of their judicial activity, as well as involvement in conflict resolution, was duly reported to the center. This seems to be a general rule in both criminal and civil cases, although in the emirate offenses were not necessarily perceived as falling into such different categories.

Let us consider cases of murder. We sometimes find that the heirs of murder victims went to judges to file claims of homicide against the suspects. In such cases, the judge usually sent his attendant (muläzim) for a preliminary investigation. Before taking such a step, he would demonstrate before the chancellery of the emir that he was legally justified in doing so by asserting that he was following an established practice among the judges of the region

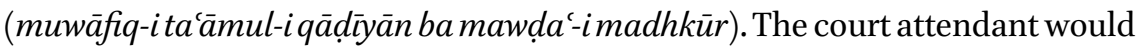
gather local notables and respected representatives of the local community and inspect the corpse for evidence of foul play. Should the attendant conclude that the deceased had indeed been murdered, the qã dī would summon the suspects. If the suspects denied the accusation, the $q \bar{a} d \bar{\imath}$ would not adjudicate the case but would instead write a report to the emir in which he informed him deferentially that a person had been murdered, that the corpse had been buried, and that there was an heir to the deceased who had filed a claim of murder. ${ }^{90}$ The $q \bar{a} \underline{d} \bar{\imath}$ would proceed to hear the case only if instructed by the emir to do so. This bureaucratic procedure often placed the judge in the awkward position of communicating to the emir his willingness to hear a claim (murāfa'a-yi ānhà rā mì pursida bāsham) in order to receive permission to rule on a case of homicide. ${ }^{91}$

Reporting to the emir did not only reflect the mechanics of a local bureaucratic system. Indeed, there were cases in which qädīs referred to the emir to secure approval for judicial procedures that might otherwise have been considered unorthodox. The Bukharan qā to the emir informing him of a case of battery and uxoricide and the subsequent detention of the murderer after confession (iqrār). The emir instructed the qā $\bar{c} \bar{\imath}$ to make a formal inquiry. As the judge proceeded to summon the

\footnotetext{
9o ìn du'āgūy murda-yi madhkūra rā dafn kunānīda da'wāgar būdan-i Mullā 'Abd al-Hamīd-i madhkūr-i wārith-i munḥașir-i way șūrat-i hāaditha malüm-i mawlāyam shawad gufta az rū-yi ghulāmī wa rị̣ā-jūy 'arḍ-i bandagì namūdam, cf. TsGARUz, f. I-126, op. 1, d. 1762, l. 16.

TsGARUz, f. I-126, op. 1, d. 1761, l. 15 .
} 
parties, the culprit subsequently denied the accusations of murder, and the four heirs to the victim relinquished gratis the claim against him. In the face of this unexpected outcome, the $q \bar{a} d \bar{\imath}$ did not notarize the statement of relinquishment (pusht-i mahdar na karda) and instead wrote to the emir explain-

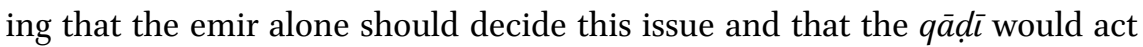
accordingly. ${ }^{92}$

As I argued earlier, the recurrent impression while reading $q \bar{a} d \bar{l} \overline{\mathrm{s}}$ ' correspondence with the emir and his ministers is that legists always felt obliged to report to the center. For example, judges recounted how they dealt with testimony as a probative procedure and thus reported the outcome of witnesses's credibility test. The procedure would entail the $q \bar{a} d \bar{l}$ informing the emir's closest minister ( $q \bar{u} s h b \bar{g} g \bar{\imath}$ ) that a party produced testimony during a hearing. The Bukharan chancellery would then instruct another judge ${ }^{93}$ (including, on occasion, the $q \bar{a}$ dì kalān ${ }^{94}$ to proceed with testing the credibility (tazkíya) of the testimony. ${ }^{95}$ The latter judge would make an inquiry into the probity of the witnesses and report to the Bukharan administration. ${ }^{96}$ The $q \bar{a} \bar{d} \bar{\imath}$ holding the hearing would then wait for further instructions from the center of the emirate.

One may wonder whether all this back and forth between the qädis and the emir's chancery was simply empty theater, in which legists made scrupulous play of their deference to the ruler while in practice simply proceeding unimpeded with their assigned job. This would be misleading. It would be difficult to account for so much ink spilled and paper wasted. Given the overwhelming number of records left by the Muslim chanceries at the time of the Russian conquest, such an idea should be dismissed outright. What is important, instead, is that the available archival evidence points not only to the increasing restrictions on the $q \bar{a} d \bar{\imath} \mathrm{s}^{\prime}$ autonomy but also to the existence of a system of prosecutorial justice according to which judges' investigations and other judicial activities were, more often than not, instigated by the state. Khorezm perhaps demonstrates this tendency most clearly. In 1910, after a particularly

92 Ibid.: l. 19 .

93 See the report of Mullā 'Abd al-Ḥamīd Khwāja Șadr Ra'is addressed to the emir, n.d., TsGARUz, f. I-126, op. 1, d. 1796, l. 14, in which the author explains that he received the instructions to test the credibility of two witnesses on account of a petition that the chief judge, Mullā Mīr Badr al-Dīn, had transferred to the chancellery. The qāọī kalān had alerted the emir that, during the hearing, the claimant had produced the testimony of two men to corroborate his claim.

94 Ibid.: l. 6.

95 Mīrzā Ṣādiq Munshī Jāndārī, Munshā’āt wa manshūrāt, Ms Tashkent, TsVRUz, no. 299: fol. 123 .

96 TsGARUz, f. I-126, op. 1, d. 1796, ll. 5, 12. 
meager harvest, ${ }^{97}$ Sayyid Islām Khwāja, grand vizier under Isfandiyār Khān (r. 1910-18), addressed the $q \bar{a}$ dīs in Astana, a town 16 kilometers east of Khiva, with instructions explaining that they should not, for example, attach their seals to certain records concerning cotton and grain. They were also instructed to redirect applicants to the royal court for matters regarding the allotment of agricultural produce and thus refrain from looking into such cases without prior authorization (bì rukhșat). ${ }^{98}$

\subsection{Trustees}

The individuals who appealed to the royal court had another instrument at their disposal. In filing a complaint with the emir's court, they could request to be assigned somebody who would act in the capacity of trustee to oversee the investigation (az barāy-i haqiqat-i ān amin talab shuda). ${ }^{99}$ Texts refer to this appointee in various terms, such as amin, ${ }^{100}$ mahram, and yasāwul. Despite this variation in terminology, the trustee was always appointed from among the court personnel (az ghulāmān-i darbār-i $\left.{ }^{\top} \bar{a} l \bar{l}\right)^{101}$ and therefore acted on behalf of the royal court. Such individuals were usually instructed to join (hamrāh) other officeholders and hold, with the latter, an official inquiry (tahqiq $)$. In this latter case, $q \bar{a} d \bar{l} \bar{s}$, for example, were officially informed about their appointment by the same trustee. The royal court entrusted to the trustee a missive of instruction addressed to the $q \bar{a} d \bar{c}$. This could be a text summarizing the case, or simply a short note on the verso side of the protocol of claim. The latter would include the statement "a trustee was requested" (amin talab shuda). On the verso, the addressee could also find a set of instructions. One such instruction reads as follows:

97 Khivan sources indicate that the harvest was so bad that it impoverished the population and obliged the royal court to take the financial situation of the country under direct control; see Isfandiyār Khān to Nil Lykoshin, 19.08.1912, TsGARUz, f. I-2, op. 1, d. 289, l. 140.

98 TsGARUz, f. I-125, op. 1, d. 579, l. 2.

99 AMIKINUz, untitled collection of Arabic-script documents: collection series no. 385 . For a description of the record, see Welsford and Tashev, A Catalogue of Arabic-Script Documents from the Samarqand Museum: doc. 239.

100 The amin apparently specialized as assessor of bodily injuries. For a case in Bukhara, see TsGARUz, f. R-2678, op. 2, d. 4, l. 1.

101 These individuals were otherwise referred to as "the men of the pen" (ahl-i qalam), that is, those officeholders who were in charge of fiscal duties and resolving claims and dis-

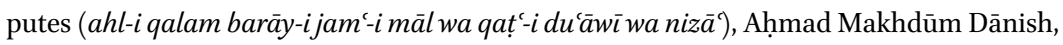
alias Kalla, Nawādiral-waqāayi', Ms Tashkent, TsVRUz no. 4266:fol. $5^{2}$ (Western pagination). 
Let it be known to the chief judge, the refuge of the law and glory, Mullā Ṣadr al-Dīn Qàdịi Kalān, that a certain plaintiff has filed a claim against a certain claimant by producing a protocol of claim. We instructed 'Abd al-Rasūl Mīrzā Bāshī Yasāwul to reach [the parties] and resolve the conflict [ farmūdìm rasīda qaț'rasānīda] ${ }^{102}$

The division of labor between the trustee and the $q \bar{a} d \bar{\imath}$ is uncertain. While we see reports emphasizing the role of judges and restricting trustees to ancillary functions, ${ }^{103}$ we know of other cases in which the two seem to have held inquiries together and together reached the resolution of a conflict. ${ }^{104}$ There is yet another variation in the relationship between them: the trustee settled the dispute, while the $q \bar{a}$ dìs solemnized the amicable settlement ${ }^{105}$ and reported to the court the outcome of the dispute. We find an example of such procedure in the following case [see Fig. 4]:

A certain Sarwar Ây from the rural settlement of Qara-Bāsh-Sarmast requested a trustee $[\mathrm{amin}]$; she came to the gates of the royal citadel and prayed in favor of my Lord. She informed [the chancellery] that a certain Faydullāh who comes from the same settlement entered her house during the night with evil intentions. He cut the hair of her daughter Gawhar $\bar{A} y$ and left. The people followed him and apprehended him. For this reason, from among the servants of the royal court of justice [darbār-i ma'dalat-madār-i ‘ālī], Sayyid Pahlawān was appointed by royal decree. He came and summoned the parties and held a trial [ämada tarafayn $r \bar{a}$ ba-muräfáa-yi shar'ìya hậ̣ir gardānìd]. [Sarwar Āy], the aforementioned

102 TsGARUz, f. R-2678, op. 2, d. 178, l. 4. On the same folio is the notarization of the defendant's delivery of money to the claimant and the latter's relinquishment of the claim.

103 TsGARUz, f. I-126, op. 1, d. 759, l. 5.

104 Zarīf Khwāja Hisābchī Mahram [...] ba-masjid-i Farr āmada mubārak-nāma-yi ‘̄ầ rā bar āwarda ba-Qāḍ̂̀ Mullā Faydullāh Khwāja du'ā-gūyishān dād ki du'ā-gūyishān mubāraknāma-yi 'ālì rā dìda būsīda ba-chashmān-i khwud mālēda fawran hamrāh-i mahram-i madhkūr bar āmada maw d̦a'i Mìrzā Qul raft ba-masjid-i Farr āmada fuqarāyān-i mawḍ̂ci madhkūr wa ațräf-i jawānib rā jam' karda muwāfiq-i amr-i 'ālī ahwwāl-i Sayyid Mukhtār wa Sayyid Murād wa Sayyid rasūl nām az ànjā būda rā tahqūq karda pursīda dīdand; cf. 'Abd al-Wahhāb Mīrshab, n.d., TsGARUz, f. I-126, op. 1, d. 1796, l. 4.

105 Welsford and Tashev, A Catalogue of Arabic-Script Documents from the Samarqand Museum: docs. 144b.i and 144b.ii. The trustee was, in this case, someone who had the title of "Yasāwul." For other such cases in which the emir Muzaffar al-Dīn appointed yasāwuls to the office of trustees to achieve the settlement of disputes that would later be notarized by qā 
claimant, [admitted that she] did not see Fayḍullāh with her own eyes and was [therefore] in doubt [gumān]. [At that point], the āqsaqāls advised her to relinquish her claim gratis. [So she did]. She made a relinquishment, and the conflict was resolved. According to the established practice [muwāfiq-i ta'āmul], the āqsaqāls took 15 tangas [from the parties] and handed them over to the trustee [yasāwul] as his travel allowance $[$ farsakh pulī $] .^{106}$

The report recounts the trial as if it were held by the servant (ghuläm) of the royal court rather than by the $q \bar{a} d \bar{\imath}$ who attached his seal to the verso of the text. Nor is the trustee who held the trial said to be assisted by any judge. It is clear, though, that the $q \bar{a} d \bar{\imath}$ was the same who notarized the relinquishment of claim. The presence of a $q \bar{a} d \vec{\imath} \mathrm{s}$ seal on the verso of the report suggests, however, that the application of the law by the royal court was in perfect accordance with the shari ${ }^{\prime} a$. If so, it seems that judicial attributes were not a requisite for hearing cases according to Islamic law. For the parties, it was irrelevant that Sayyid Pahlawān represented sharīa by virtue of a specific judicial title. They were more interested that the representative of the state and its prosecutorial judicial system be fully involved in their dispute.

In nineteenth-century and early-twentieth-century Bukhara, one could file a lawsuit with the royal court and avail oneself of a trustee to adjudicate his/ her case without necessarily involving the judges. Following is an illustration of this procedure:

A certain Manșūr Bāy came to the gates of the glorious citadel and prayed to our Lord. He said that he had entrusted to the custody [amannat] of his uncle Șābir Bāy one țanā $b^{107}$ [of land] of his own, tax exempt [milk$i$ hurr], two țanābs of garden land [chahār bāgh], and one courtyard (hawīlì). [All these properties can be found] in the locality of Būkhūn Pīr. When [Manșūr Bāy] demanded [the restitution of his wealth, Șābir Bāy] disobeyed. A trustee [amin] was requested; [accordingly] Raḥmatallāh Bìk was appointed [to this office]. He brought the diploma of noble rank, greeted and thanked [us], and immediately instructed a man to summon the defendant, together with the respected people of the locality

106 Excerpt from TsGARUz, f. I-126, op. 1, d. 1762, l. 11. The verso side bears the seal of Qādī Mullā Muhammad Idrīs Khwāja, 1293 [1876].

107 The tanāb was a unit of land measurement in Central Asia of approximately 0.4 hectares. See E. Davidovich, Materialy po metrologii srednevekovoi Srednei Azii (Moscow: Nauka, 1970): 128. 


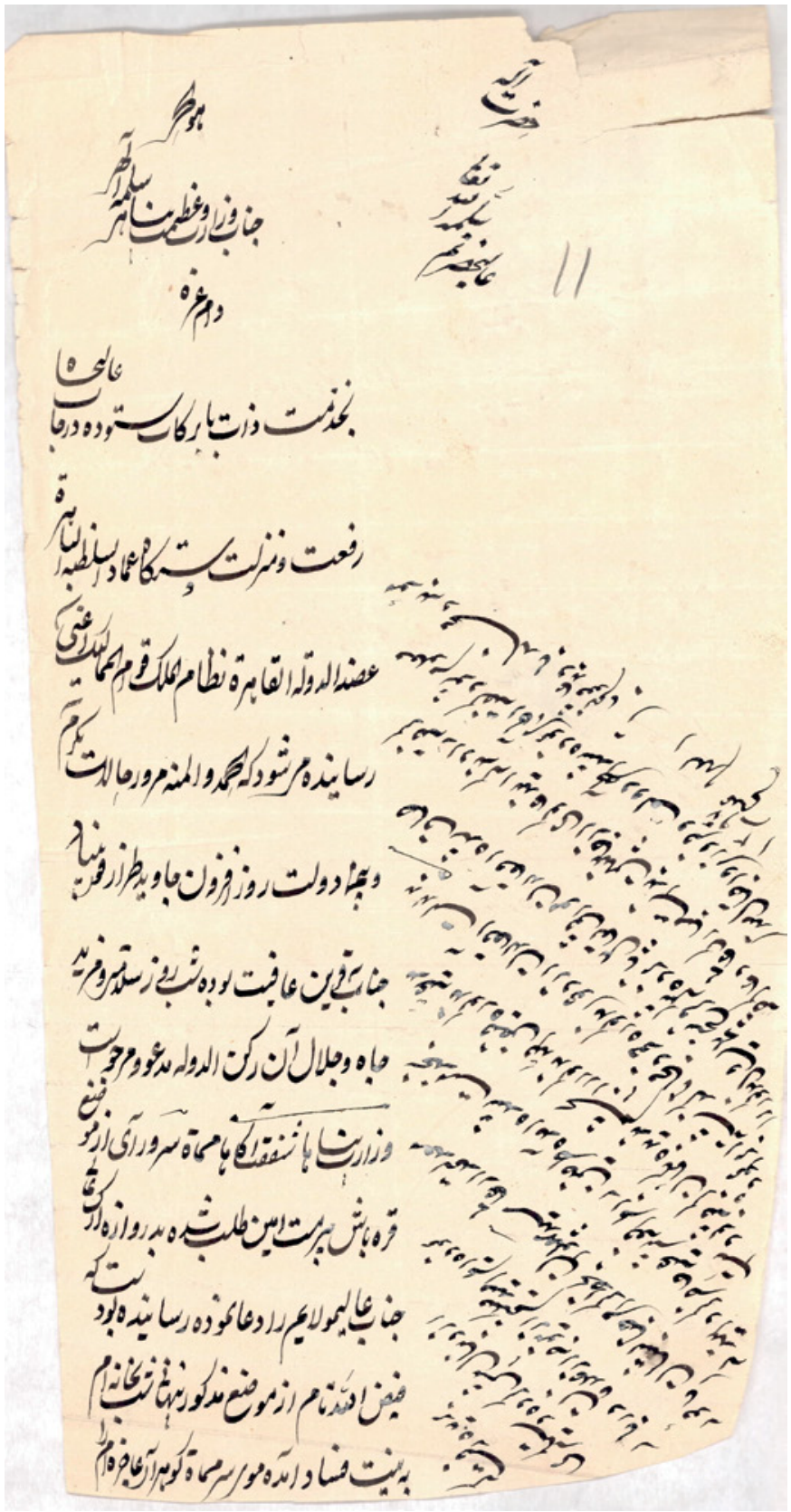

FIGURE 4 Qādī's report to the royal court in Bukhara, n.d. TsGARUz, f. I-126, op. 1, d. 1762, l. 11 . COURTESY OF THE CENTRAL STATE ARCHIVE OF UZBEKISTAN 
[mackalān-shawandigān-i mawda]. He [then] heard the conflict according to the noble law ['ala hasbu 'l-shar'-i sharîf]. [Assisted by] virtuous $\bar{a} q s a q \bar{a} l s$, he relinquished the plaintiff's claim in exchange for one hundred current tangas and thus reconciled the two parties. He paid to this man of noble rank [the trustee] a travel allowance for the service he had provided, according to local custom and practice [az rū-yi 'urf wa ta āmul farsakh pulī-khidhmatāna girifta dāda.$^{108}$

The royal court followed this procedure in overseeing all sorts of civil lawsuits, which could involve disputes between individuals, ${ }^{109}$ such as the one we have examined, or larger constituencies of people, such as pastoral and tribal groups who came into conflict over the delimitation of property rights. One such case was a dispute between the Yūqāqchī and the Kazakhs, which involved garden land and a small piece of tax-privileged land. When the plaintiffs filed the lawsuit before the royal court, they produced a protocol of claim and requested a trustee. A certain Sulaymān Bīk was appointed to the office. The record relates that he came in person to the place of the dispute, summoned the two parties, and held an inquiry according to Islamic law (bar wafq-i shar-i sharîf pursìda). During the hearing the $\bar{a} q s a q \bar{a} l s$ reconciled the parties, and the plaintiff relinquished his claim in return for ten tanābs of land liable to the payment of the tithe. The parties paid for the service (khidhmatāna). ${ }^{110}$

Submitting a formal request for a trustee was a way to ensure that the royal court would be fully involved in hearing the claim, whatever its nature. The royal court did not react only to financially significant cases, nor did it assist individuals whose standing would require that the men in power pay particular attention to them. The royal court did not discourage claimants from bringing unedifying stories of petty brawls, nor did Bukharan officials refrain from intruding into marital discords and personal grief. Reviewing the following case may serve to illustrate the degree to which the people of the Bukharan emirate were aware of the services provided by the royal court and

108 Excerpt from report to the Qūshbīgī, TsGARUz, f. I-126, op. 1, d. 1003, l. 22.

109 See the case of repayment of a debt (qarḍ) of 14,00o tangas involving a certain Shādī Murād Tarāzūdār from the locality of Bāgh Ḥaydar against "a few Muslims" (chand nafar musulmān). The case was adjudicated by 'Abd al-Raḥman Bīk Chihra Āqāsī after the plaintiff had appealed to the royal court and requested the appointment of a trustee (amīn); see report to the Qūshbīgī dated 1318/19oo-1, TsGARUz, f. I-126, op. 1, d. 967, l. 10.

110 See anonymous report to the Dīwānbīgī dated 1318/1900-1, TsGARUz, f. I-126, op. 1, d. 1003, l. 28 . 
made extensive use of them. A certain Sharīfa Bīgīm from Kumūsh Kent-in the Kāmāt district, close to present-day Vobkent, north of Bukhara-claimed approximately 16 tanābs of land, one courtyard, one building for agricultural tools (amläk-khāna), and four thousand tangas in cash against her husband, a certain Luțullāh. She went to the royal citadel, prayed for the wellbeing of her Lord, and requested the appointment of a trustee (amin talab shuda). The court accordingly issued a diploma designating Shāh Murād Bỉk as trustee. Shāh Murād Bīk went to the place with an attendant, summoned the parties, and questioned them according to Islamic law (țarafayn rā ba-muräfáa-yi

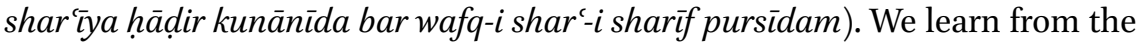
record of the adjudication that Luțfallāh agreed to divorce his wife irrevocably (yak talāq-i bāyin harāam gardānīda) in return for five hundred tangas and a half tanāb of land. The parties expressed satisfaction, and the conflict was resolved. Shāh Murād Bīk was paid for his service according to local custom ( $a z$ rü-yita'âmul). So reads the case in the rescript sent to the emir's chancellery.111

Why did Sharifa Bīgìm go to the royal court? The fees the qā dìs charged their clients were certainly not the reason for Sharifa Bīgim to prefer the trustees. In fact, referring to the royal court cost no less than adjudication. People regularly complained that trustees charged more than the norm, ${ }^{112}$ and we find that the Bukharan administration had, on more than one occasion, to regulate their tariffs.

People were free to pick a court in order to maximize their own investment and gain an advantage. It would thus be fair to assume that the royal court represented, in the eyes of the appellants, an institution different from the $q \bar{a} d \bar{\imath} \bar{s}$ ' court. Indeed, judicial summons issued in Khorezm, for example, inform their addressees that they should resolve their conflicts either before the $q \bar{a} d \bar{l} \mathrm{~s}$ (sharîatgha kilīib) or by requesting a trustee from the royal court (khāndin yasāwul). ${ }^{113}$ Such petitions to the ruler seem to attest to "forum shopping."114

111 Anonymous report addressed to the Qūshbīgī in 1321/1903-4, TsGARUz, f. I-126, op. 1, d. 1003 , l. 23 .

112 ba-dawlat-khāna masmū' shuda ast ki ba-tūmānhā az wajh-i janjāl wa murāfáa-yi fuqarā ba-qā dīkhānahā pul bisyār az fuqarāyān pursīda kharj wa kharājāt bisyār shuda mahrāmm wa māmmūr khidhmatān [a wa] kharājāt pul̄ rā bisyār mïgirifta-and, TsGARUz, f. I-126, op. 1, d. 754, l. 3; az wajh-i janjāl wa murāfáa-yi fuqarā ba-qā d̦i-khānahā pul-i bisyārī az fuqarāyān bar āmad shuda chand rūzjanjāl wa murāfáa țūl yāfta, ibid.: l. 4.

113 TsVRUz, Khiva qozilik khujjatlari, docs. 426, 657, 789. See the description of these documents in Katalog Khivinskikh kaziiskikh dokumentov (XIX-nach.XXvv.): same numeration.

114 K. von Benda-Beckmann, "Forum Shopping and Shopping Forums: Dispute Processing in a Minangkabau Village.” JLP 19 (1981): 117-59. 
Observing that people were free to choose the most convenient site of redress, however, does not mean that royal and $q \bar{a} d \bar{\imath} \bar{\imath}$ courts were mutually exclusive sites of adjudication nor that they applied fundamentally different procedural laws. Evidence like that cited above points to the trustees' following substantive legal doctrines or antecedents that were deep-seated in the local traditions of Islamic law. As we have seen, reports to the ruler suggest that both trustees and $q \bar{a}$ dìs heard cases according to Islamic law-or, at least, that is what sources would lead us to believe. Conventional legal formulas appear indiscriminately in the records they produced. There was a tendency among trustees and $q \bar{a}$ ḍis to solemnize extrajudicial mediation achieved by a third party, thereby avoiding confrontation and the passing of judgment. We also find many cases in which trustees and $q \bar{a} d \bar{l} \bar{s}$ cooperated. Though the royal trustees and the sharīa court of the $q \bar{a} d \bar{\imath}$ s may well have been perceived by the people as different legal resources, the Islamic juridical field in fact included both, as both were answerable to the state. The main difference between them, therefore, was less procedural than logistical. Qādīs operated within convenient reach, as they were appointed to regional locales; enjoying the services of the trustees, on the other hand, required one to travel to Bukhara or Khiva, file a claim there, and cover the trustees' expenses during their investigation.

In general, bringing one's grievance to the emir or the khan was a means of limiting judicial discretion. In other words, filing a lawsuit in Bukhara or in Khiva was a rejoinder to some local $q \bar{a} d \bar{\imath} \bar{l}$ and a means of shifting the case away from local power holders. In this sense, resorting to the ruler or the local governor ${ }^{115}$ rather than a $q \bar{a} d \bar{\imath}$ reflected a general recognition of forms of social control. The ordeals of Baqā Khwāja, another scholar whom we encountered earlier, are paradigmatic for our purposes. It seems that, in the wake of his appointment in Kerki (an important trading post of the emirate on the Amu-Darya, now in Turkmenistan), during the time of Emir Muzaffar al-Dīn (r. 1860-85), he found it difficult to come to terms with the customs of the Turkmens. Disapproving of how local notables welcomed him with gifts of carpets, he obstinately rejected their offerings by packing them back on the shoulders of his visitors and chasing them away. Appalled at how the majority of the Turkmens were engaged in what he regarded as bribery ('âdat-i akthari turkmānāyan pāra-khwur wa rishwat-khwur) he complained about the matter before the local governor who, however, sided with the locals and wrote to the Emir accusing Baqā Khwāja of malpractice. The story relates that the royal court sent an envoy (tahqīqchì) and that the subsequent investigation led to

115 Fatwa in which someone is said to have appealed to the governor, Tashkent 1865 , TsGARUz, f. I-164, op. 1, d. 13, l. 5 . 
Baqā Khwāja's removal from office. ${ }^{116}$ It appears, therefore, that the Turkmens were thus able to avoid being subjected to a new judicial regime and got rid, at least this time, of the Bukharan jurist. The story should alert us to just how far the fortunes of a qā $\bar{l} \bar{\imath}$ depended on the favor of the populace.

Complainants knew that no appointee to the position of judge could enjoy full institutional exclusivity. Materials from early-twentieth-century Bukhara indicate that Muslims brought their affairs to state officials because they had the power to coerce parties to achieve a settlement and enforce a decision, either formal or informal. Reports such as the following show provincial governors expanding their powers in the legal sphere:

Our servant and his sons, who were assigned to the districts of Mìr and Tātkint, interfered [dākhil] with the work of the judges [qā dì wa ra’is]. They assigned their own man to [oversee] every dispute [har janjäl], and they did not refer to the qädiss. They themselves held inquiries [murāfa'a pursīda], attached their seals to certificates of relinquishment and acknowledgement [ba-khatțhā-yi ibrä’ wa iqrārī muhr karda], and reconciled [the disputing parties]. I went to visit your servant on Saturday. I told him that His Majesty and the governors of the provinces defer all the affairs of their subjects to the $q \bar{a} d \bar{c}$ s and refer to the noble law. They do not let the established practice of the governor and people of authority [ta'ämul-i hăkim [wa] shawandigān] affect the work of the judges. Your servant said, "The established practice in this province is such that, if the people come to me [with their disputes], I solve them. I do not send them to you. If they come before you [with their problems, then] you solve them. This is not my business." This was his answer.117

Personal relations had a bearing on the way people chose to solve their problems. Parties would always prefer to try their luck in the court of the emir or the local governor if, in doing so, they were able to avoid some legal functionary for whom they had little sympathy. When a $q \bar{a} d \bar{\imath}$ was not familiar to the community, for instance, people were often suspicious that he might cause oppression (jabr wa nafsānōyat) by neglecting their corporate interests.

116 Ḥamīd Khwāja, Tanzīl al-imthāl fì dhikr bayān al-aḥwāl, Ms Tashkent, TsVRUz, no. 6o2: fol. 9ob-91a.

117 TsGARUz, f. I-126, op. 1, d. 759, l. 8. For another case of a local governor resolving disputes without referring the cases to the judges, see TsGARUz, f. I-126, op. 1, d. 759, l. 33 . 
In one such case, petitioning the royal court allowed the community to have a local mullah appointed as deputy judge $(n \bar{a} i b-i q \bar{a} d \bar{\imath}) .{ }^{118}$

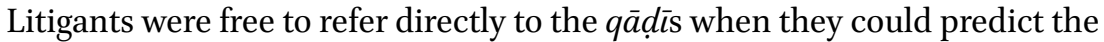
outcome of a case or more simply instrumentalize judicial procedures as they saw fit. In what follows, the celebrated Bukharan intellectual Șadr al-Dīn 'Aynī recounts a dispute initiated by a certain Yahyā Khwāja (a pious scholar known in the city for scolding the official clergy and the court attendants for their laxity) against a mullah, a certain Qārī Samī's, who used to parade his piety with a large rosary and made a living exploiting the people's credulity. Yahyā Khwāja forged a set of legal documents (hujjathā-yi sākhta-yi shar $\tilde{\imath}$ ) with reference to which he accused Qārī Samī` of usurping his courtyard, and "dragged him to a qā $\bar{l} \bar{\imath}$ court". The dispute made it to the office of the chief judge, who ruled that Qārī Samī should pay 15,000 tangas in exchange (badal) for the courtyard. But Yahyā Khwāja agreed to the notarization of an amicable settlement (șulh-nāma) between the parties, on condition that Qārī Samī‘ deliver the sum in cash before the qā $d \bar{\imath}$. The defendant complied with this condition and brought the cash to court. When the judge was about to notarize the relinquishment $(i b r a \bar{a})$ of the claim and the delivery (taslim) of the sum, the plaintiff asked him not to attach the seal. Yahyā Khwāja explained that he would temporarily return the money to the defendant in trust (be-tarz-i amānat) and therefore asked the qā $\bar{d} \bar{\imath}$ that he be given back the deeds he had forged. He thus explained to the judge that, if Qārī Samī promised not to wave his rosary at people and perpetrate any deceit, he would withdraw his claim; otherwise, should Qārī Samī‘ again indulge in fraud (harakathā-yi farībgarāna), Yahyā Khwāja would file the same claim and request compensation by means of a settlement (badal-i șulh rā țalab khwāham kard). ${ }^{119}$ There is little doubt that, before filing the claim directly with the $q \bar{a} d \bar{c} \bar{\imath}$, Yahyā Khwāja could foresee what would happen and thus manipulate the judge.

\section{On the Public Dimension of Law}

To rethink the contours of the Islamic juridical field of Central Asia requires that one count the populace among the legal actors operating in such a field. They were those who took legal action and thus activated the legal system

\footnotetext{
118 Ibid.: 1. 42.

119 Șadr al-Dīn 'Aynī, Yāddāshthā, ed. Jacfaruf (Stalinabad: Matba'a-yi Wizārat-i Madaniyat Rss Tājikistān, 1959): 3:12-14.
} 
that I have described. They were the recipients of justice. They were, most certainly, not part of the legal profession and, as such, they had to rely on the legists and the 'ulama' for expert knowledge. They knew something, however, and that was enough to push them to take legal action and pursue redress. It informed people's assumption about their entitlement and about what they thought was right or wrong. We may term this "common knowledge."

Speaking of assumptions about legality inevitably leads us to discuss what people know and what the "ways of knowing" are. How do we do that? Some would follow a commonsense approach and attempt to disambiguate information from knowledge, as did Peter Burke in A Social History of Knowledge. Burke noted that "We $[\ldots]$ need to distinguish knowledge from information, 'knowing how' from 'knowing that,' and what is explicit from what is taken for granted, $[. .$.$] what is relatively 'raw, specific, and practical' [\ldots]$ [from] "what has been cooked, processed, or systematized by thought.'"120

The utility of such an approach is questionable, because usually, for all intents and purposes, individuals become informed about things as elaborate as taxation, recipes, or witchcraft that had been already reflected upon by other people and that were the outcome of a cognitive process in someone else's head. ${ }^{121} \mathrm{~A}$ more practical way of approaching the problem would be to adopt the conception of knowledge as used by the anthropologist Fredrik Barth. By "knowledge," Barth means "feelings (attitudes) as well as information, embodied skills as well as verbal taxonomies and concepts: all the ways of understanding that we use to make up our experienced, grasped reality."122 Knowledge, according to this understanding, consists less of a corpus of disconnected information than of dispositions for interpretation: "knowledge provides people with materials for reflection and premises for action."123

120 P. Burke, A Social History of Knowledge: From Gutenberg to Diderot (Cambridge: Blackwell Publishers, 2000): 11.

121 I am drawing here on S. Subrahmanyam, "Between a Rock and a Hard Place. Some Afterthoughts." In The Brokered World: Go-Betweens and Global Intelligence, 1770-1820, ed. S. Schaffer et al. (Sagamore Beach, MA: Watson Publishing International, 2009): 432.

122 Fredrik Barth, “An Anthropology of Knowledge." Current Anthropology 43/1 (2002): 1.

123 Ibid. Barth's definition of knowledge is close to what Jay Smith calls "interpretive disposition," that is "a set of disparate beliefs and assumptions whose cumulative effect produces a general moral sense and a particular view of the world." J.M. Smith, "Between Discourse and Experience: Agency and Ideas in the French Pre-Revolution." History and Theory 40 (2001): 141-2. 
In nineteenth-century Central Asia, common knowledge about law was part of what Daniel Lord Smail termed a "public archive": ${ }^{124}$ a common knowledge about the law existed simply because certain legal practices were performed in public and because people's memory about such practices was relevant to the preservation of local traditions. One wonders how otherwise to explain the existence, for example, of so many private collections of Islamic legal deeds in Central Asia. It must have been common knowledge that, if one wanted to safeguard one's rights, one should keep at the ready pieces of evidence to deploy in court and that to safeguard said rights (to a plot of land, for example) required the acquisition and preservation of those documents in which those rights were attested. ${ }^{125}$ There is presumably nothing particularly difficult about learning the basics of the Islamic law of evidence as it was practiced in Central Asia: a plaintiff would first be asked to produce testimony (bayyina) in support of a claim; written attestation to certain rights would serve the same purposes in court. In a legal culture that accorded preeminence to oral testimony, there were jurists who, in the nineteenth and early twentieth centuries, recognized the probative value of deeds. ${ }^{126}$ The following fatwa illustrates such a phenomenon:

[Question:] We invoke blessing in the name of the supreme Lord. What do the imams of Islam - may God be pleased with them all—have to say on the following question? The matter is as follows. It happened that Mullā Mīr Bābāy Muftī had a sound and legal debt [dayn] for a certain amount of money that constituted the financial obligation of Bābā Bāy. In the condition that allows the acknowledgment and the execution of all the usufructs, the aforementioned Bābā Bāy legally acknowledged before a community of Muslims the aforementioned debt and had a legal

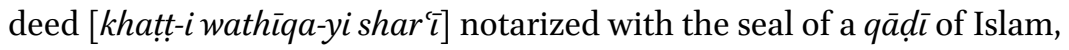
which deed he entrusted to Mullā Mīr Bābāy Muftì. In this case according to the Sunna of Muhammad and his legal doctrine [...] and the school

124 D.L. Smail, The Consumption of Justice: Emotions, Publicity, and Legal Culture in Marseille, 1264-1423 (Ithaca, NY: Cornell University Press, 2003): 211.

125 This is well exemplified in T. Welsford, "Fathers and Sons: Re-Readings in a Samarqandi Private Archive." In Explorations in the Social History of Modern Central Asia (1gth-2oth Century), ed. P. Sartori (Leiden: Brill: 2013): 299-323.

126 Consider the following legal opinion: "Isn't it the case that the deed (wathiqa) in possession of the aforementioned purchaser and which was drawn in accordance with the ruleds, is relevant, binding, and applicable? Yes." A Catalogue of Arabic-Script Documents from the Samarqand Museum: doc. 375. The use of deeds in court may help a respondent to deny a claim; ibid.: $493,496,512$. 
of law [madhhab] of Hanīfa, if the aforementioned Bābā Bāy denied the claim [munkir] for the said sum of money or if he says that he has already delivered said sum of money, then this deed should be considered a piece of evidence [in khațt-i wathīqa-yi madhküra hujjat bāshad] that the aforementioned sum [needs to be paid], isn't that true? Explain and be concise.

[Answer:] Yes, it is, and God knows best. ${ }^{127}$

Popular knowledge expanded beyond the functionality of deeds. People were acquainted also with certain juristic principles. A Bukharan subject evidently knew that, if the dead body of his wife was found together with the corpse of the man who purportedly cuckolded him, he would stand a good chance of avoiding retaliation because the killing would be understood as a heat-ofthe-moment action. The following example introduces us to the details of one such homicide case: a Bukharan notable $(b \bar{a} y)^{128}$ was accused of having killed his wife and a man under two different circumstances and having adjoined the corpses so as to give the impression that he had killed them after having found them during the sexual act. The aggrieved party held that he had manipulated the murder scene so that this double murder would be treated as a case of manslaughter ( $h a d r)$, that is, unintentional homicide. ${ }^{129}$ If so, he would have been held accountable only for the payment of blood money and thus avoided retaliation or the payment of a larger sum [see Fig. 5]:

127 Anon., Jung, ms Tashkent, TsVRUz, no. 6102: fol. 331b. The opinion can be dated inductively on the basis of various seals, as about mid-nineteenth century.

128 It is current among students of Central Asian history to translate $b \bar{a} y$ as "wealthy landowner" or "rich man." This is problematic, because such a definition is based on Soviet bureaucratese of the 1930s and does not take account of the fact that, in Khorezm, ba $\bar{y} y$ was an official administrative position. This we learn from a series of diplomas retrieved in the province of Urgench, which show that individuals holding the title of $b \bar{a} y$ (along with katkhudās, "steward") enjoyed fiscal privileges (tarkhān/suyūrghāl) because they worked in some official capacity for the royal court (dawlat-khwāh khādim wa kār-āgāh mulāzimlārimìz). I have consulted deeds of fiscal immunity now held in the private collection of Komiljon Xudoybergenov.

129 A. Layish, Legal Documents from the Judean Desert: The Impact of the Shari'a on Bedouin Customary Law (Leiden: Brill, 2011): 40. 
On 8 Muharram 1306 [14.09.1888] Aḥmad Bāy from the [jural] community [jamā'a $]^{130}$ [called] Îskī came before 'Abd al-Sattār Bīk Tūqsabā and Qāḍi Sayyid Mullā Jalāl Ra’is. He prayed for [the well-being of] the ruler and reported: "I saw a certain Khidhīr Bāy in my household at midnight together with Tūkhta Āy, my wife. One [was lying] over the other, and I killed them." [...] In light of his confession, we arrested the man, and we ordered two of our men, together with five or six men from among the notables of the province, [to inspect the murder scene]. They went and ascertained that the two persons assassinated were naked, that one was [lying] on the top of the other as though they had had intercourse [ ba ha'iyat jamā' mikardagī]. The [members of the jural] community to which the two assassinated belonged, say that: "The murderer was in fact unacquainted with Khidhīr Bāy, that they had an altercation [khușūmat] and that one murdered the other; then he [Ahmad Bāy] took [the corpse] from there and put it over his wife after he had murdered her. [The man and the woman killed] are not guilty [bi-gunāh]. The blood money for the murdered persons found in one place is less than if they had been killed in two [different] places; [in this case, however,] the blood money should be higher." After one night and one day, the [jural] community of the two murdered persons came and said that [they saw] blood traces more than seven $\tan \bar{a} b s^{131}$ from the household of the murderer and that traces of a scuffle were also visible. ${ }^{132}$

This case of a doctored murder scene is not unique among homicide cases in Bukhara. ${ }^{133}$ In the wake of a judicial report to the royal court, for instance, the emir ordered one of his attendants to solicit from a jurist a legal opinion addressing the possibilities of double murder. The mufti held that "if the two were murdered in one place and their blood was spilled there, their blood money should be of an amount appropriate to compensation for manslaughter

130 It appears that the author of the text confers on the term "community" (jamāca) specific attributes of communal organization that I do not understand. It is clear, however, that the community as a legal entity could produce evidence on behalf of its members. On the jural community, see F.H. Stewart, "Customary Law among the Bedouin of the Middle East and North Africa." In Nomadic Societies in the Middle East and North Africa: Entering the 21st Century, ed. Dawn Chatty (Leiden: Brill, 2006): 242.

131 It is unclear why here the author employs tanāb as a measure of lenghth, while the term is usually defined as a measure of area.

132 See TsGARUz, f. I-126, op. 1, d. 1761, l. 4.

133 Another such case in which two dead bodies were placed together, apparently to diminish the amount of blood money, can be found in TsGARUz, f. I-126, op. 1, d. 1761, l. 6. 


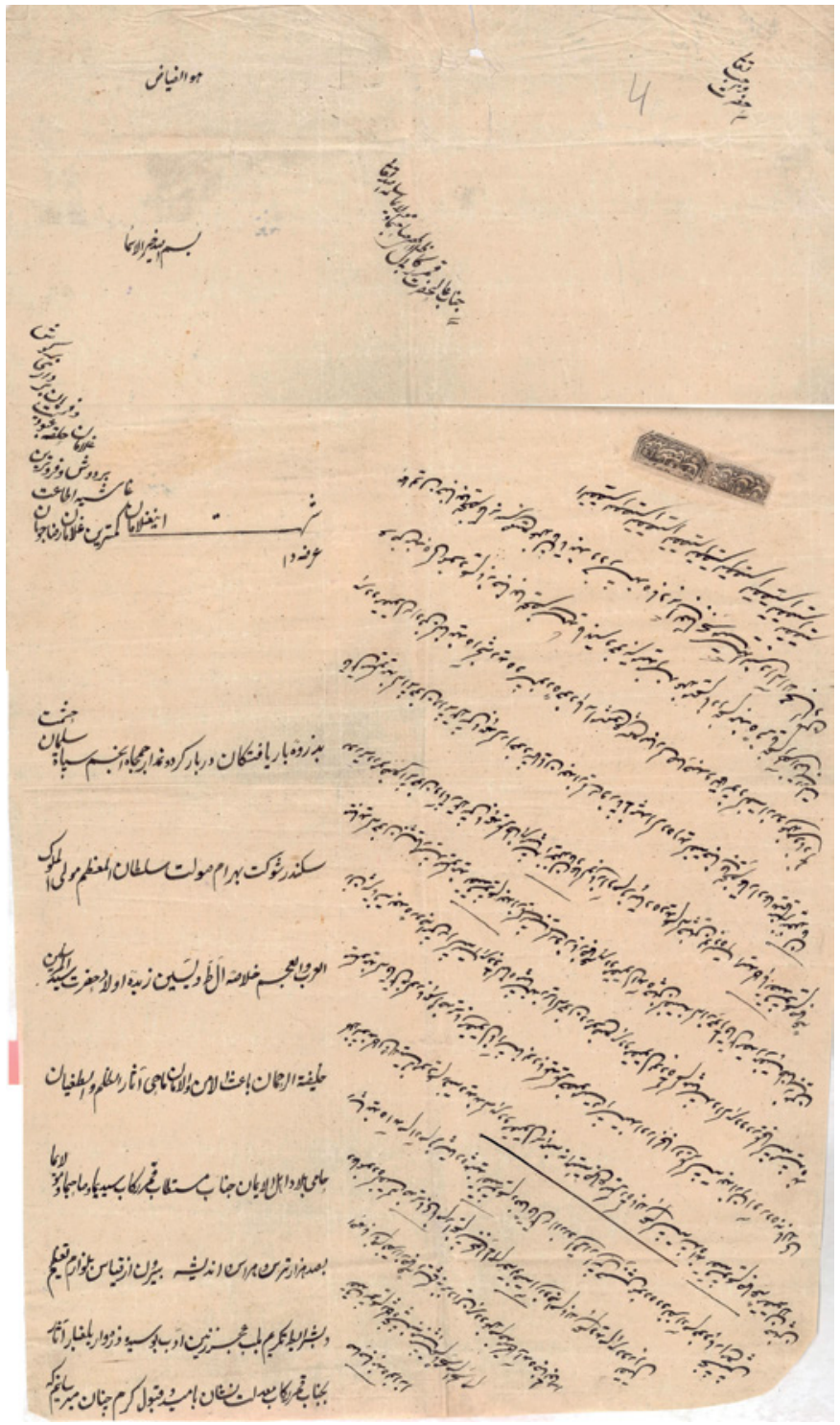

FIGURE 5 Judicial report to the royal court in Bukhara, n.d. TsGARUz, f. I-126, op. 1, d. 1761, l. 4. COURTESY OF THE CENTRAL STATE ARCHIVE OF UZBEKISTAN 
[khün-i ānhä hadr mïbāshad]. Therefore, nothing is incumbent on the murderer [ba-quatilli madhkūr chïzi läzim namishavad]. Should the heirs to the murder victim hold that they were killed unjustly [ba-nā haqq kushta], they should file a claim, and the [accused] murderer should swear an oath."134

If members of a jural community from the back of nowhere were cognizant of such juristic proscriptions and their consequences, it would be fair to assume that there was a space of shared knowledge in which the populace could learn about proscriptions from the specialists. Central Asian records account for legal actions, in a mixture of legalese and local parlance, that reflect a meshing of cultural practices blending the professional exercises of jurists with the lay comments made at the teahouse: in cities such as Samarqand, Bukhara, and Khiva, where madrasas covered much of the urban landscape, we can assume that people from all backgrounds shared a minimum knowledge of the law.

I am not arguing in any way against the legists fulfilling the role of the legal experts: as we have seen, in diplomas of appointment to various legal offices we find that qädīs and muftis alone should fulfill specific duties and enjoy prerogatives on account of their profession. Among nomads, too, the person performing judicial duties enjoyed a monopoly on violence in cases of deviation from Islamic law. ${ }^{135}$ What I suggest is different. It is a matter of fact that ordinary people, too, monitored carefully the boundaries of the law and denounced deviations from what was deemed local or customary practice.

The records produced by the chancellery of the Bukharan emirate or the Khivan khanate show that categories of justice and morality, as well as notions of procedure, were intelligible to ordinary people: a woman could thus categorize a domestic beating as an offense before the jurist translated it into a case of battery. ${ }^{136}$ One wonders how otherwise to explain the fact that women filed cases of assault without the intervention of jurists. Consider, for example, the case of a certain Yakhshī Murāt who had assaulted his wife Saādat Bīka

134 See ibid.: 1. 25. For the application of this procedure, see ibid.: 1. 7: the perpetrator of a double murder was apprehended and questioned. He stated that he saw his wife during illicit intercourse with a man and killed both of them. He swore an oath (sawgand $k h \bar{u} r d a$ ). The legists entrusted to him a certificate of manslaughter (khatt-i hadr), which would probably have favored the payment of blood money.

135 "Let him punish those who opposed the command of the noble law" (shar'-i sharif amrīgha mukhālifat qülghānlārgha ta'zìr ūrūb). This sentence is found in a diploma from the royal court of Khiva, which conferred the appointment of a man to the office of judge and moral inspector ( $q \bar{a} z \bar{l}$-ra $r a \bar{s}$ bi 'l-istiqlāl) among the Khițāy, a tribal group (țāyfa) of the Qaraqalpaq confederation $(\bar{u} l \bar{u} s)$. Shawwāl 1255/December 1839. Private collection of Abdusalim Idrisov, Nukus, Qaraqalpaqstan.

${ }_{13} 6$ See the report addressed by the governor of Gürlen to the chamberlain (yasāwulbāsh $\bar{\imath}$ ) in Khiva, Rabī` al-Awwāl 1335/January 1917, TsGARUz, f. I-125, op. 1, d. 498, 1. 28. 
and consequently left the conjugal dwelling. Niyāz Bỉka, the mother of the injured party, appealed directly to the royal court in Khiva. No doubt Niyāz Bîka recognized fully the legal resources available to her, as she must have sensed that bodily harm (majrüh $)^{137}$ constituted a legal category for which one could pursue redress.

The acquisition of legal categories and the formation of certain assumptions about right and wrong were all inevitable for the populace because the law had a public dimension. First of all, law was practiced in public. Hearings, for example, were held in the open, in the presence of bystanders. Legal deeds were notarized in front of several individuals. I speak here not of professional

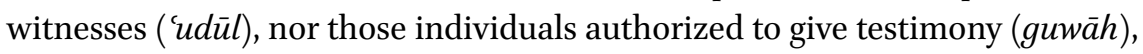
but of the requirement in Central Asian Islamic legal deeds that documents be notarized before a gathering of people in court (hudd âr-i majlis) [See Fig. 6].138 The people in question were presumably local notables, but their presence created a bond between the court and the wider populace, ensuring that what took place in court could later be recounted elsewhere in public. When a person died, the wealth to be divided among her heirs would usually be described

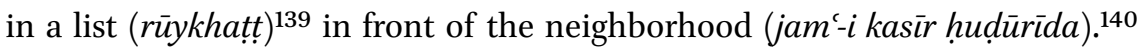
This public practice contributed to creating entitlements and, more generally, a sense of how a family wealth should be divided among the heirs.

People knew that what they said had a bearing on inquests. Everywhere, rumors and hearsay will provide circumstantial evidence. ${ }^{141} \mathrm{~A}$ certain course of action acquired a particular legal force if done in public. If someone, for example, stated in front of others that he owed money to another person, the acknowledgment of such a debt would be inscribed in the memory of the local community, and the people who witnessed such a statement must have known the implications of this admission. ${ }^{142}$

137 Jarh, in Layish, Sharîa and Custom in Libyan Tribal Society: Glossary 292.

138 See, e.g., the division of the inheritance of one Qilich Bāy notarized by a qā 1864. At least three people in addition to the witnesses were present at the notarization; see Katalog Khivinskikh kaziiskikh dokumentov: doc. 587 .

139 For a description of one such case in Bukhara, see Ḥamīd Khwāja, Tanzīl al-imthāl fì dhikr bayān al-aḥwäl: fols. 10ob-101a.

140 Katalog Khivinskikh kaziiskikh dokumentov, doc. 236. I checked the document at TsVRUz, Khiva qozilik khujjatlari: doc. 236. See also TsGARUz, f. I-125, op. 1, d. 486, l. 124.

141 Gürlen $q \bar{a}$ ḍ̂̀s' notification to the yasāwulbāshī in Khiva, 6 Rabī' al-Thānī 1335/30.01.1917, TsGARUz, f. I-125, op. 1, d. 498, l. 75. The elders provide circumstantial evidence based on hearsay in a case of disputed property between private individuals and the endowment of a mosque community.

142 A Catalogue of Arabic-Script Documents from the Samarqand Museum: doc. 69 . 


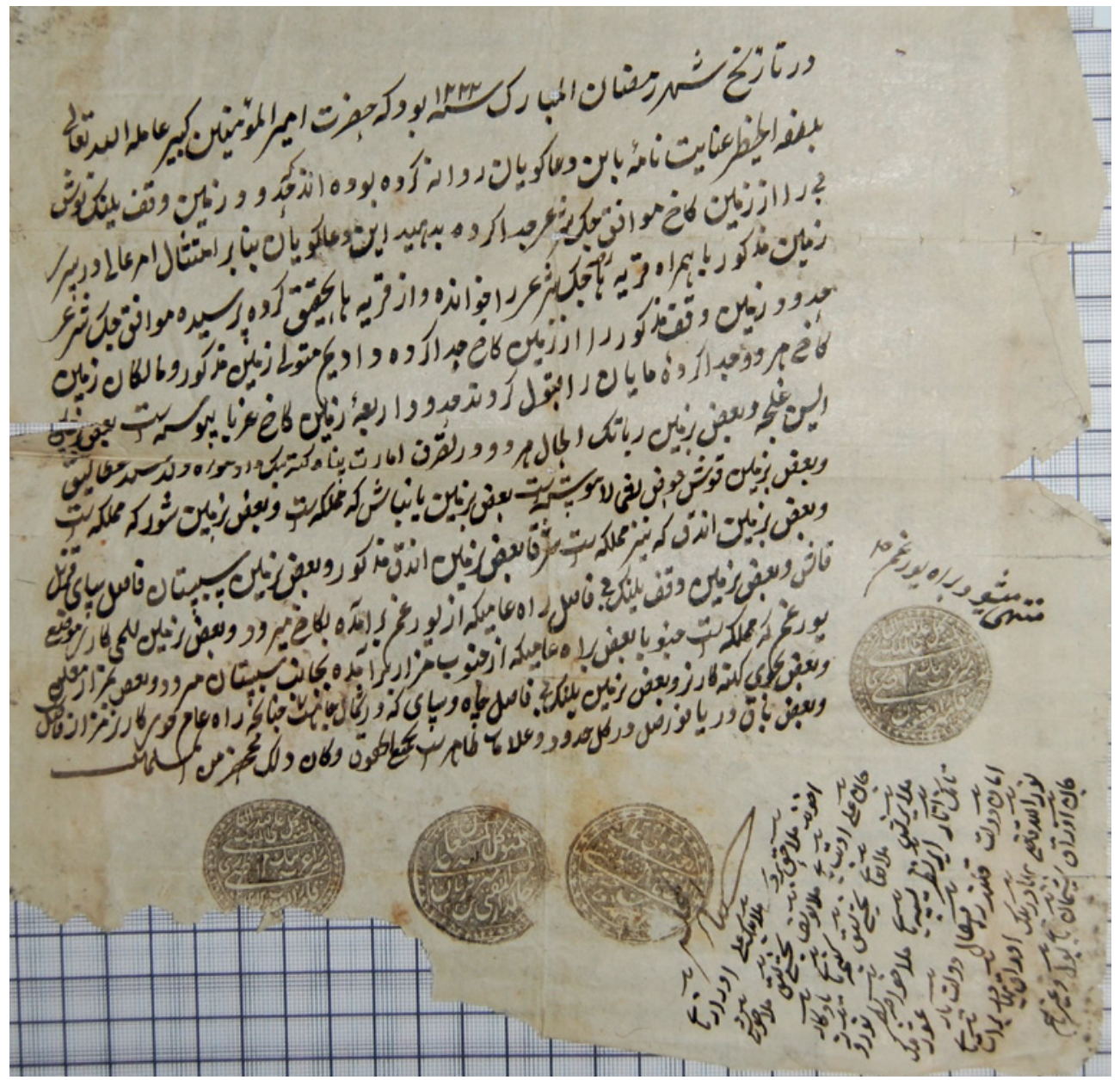

FIGURE 6 Rescript addressed to the royal court of Emir Haydar (1807). Three legists notarized the demarcations of waqf land in Käkh. Twenty-nine individuals participated in the notarization as huḍ̣ār-i majlis. ${ }^{143}$ COURTESY OF THOMAS WELSFORD

The fate of a culprit depended also on the public's disposition towards him. The choice between entrusting a culprit to a guarantor ( $k a f i l)$ and jailing him required one to consider his reputation and determine the consequences of such a decision for the social relationships of the parties and the

143 The document is described in Welsford and Tashev, A Catalogue of Arabic-Script Documents from the Samarqand Museum: doc. 415. 
community to which they belonged. After a robbery somewhere in Khorezm, ${ }^{144}$ for example, the victim followed the trail of the thieves, caught one of them, and took him before a local governor (hākim). The latter threatened to use violence (sīyāsat) against him. Under threat, the suspect confessed (iqrār) his crime and provided the names of his two associates. As the latter were found and it was ascertained that the three men had indeed perpetrated the crime (jināyat), the case was settled by the official representatives of a local community who arranged for monetary compensation to the victim. The governor thus notified the royal court and asked for further instructions. In so doing, he asked whether the thieves should be detained or sent to Khiva. But there was a third option available, handing the culprits over to a guarantor. Because the guarantor was responsible for the culprits' behavior, the guaranty placed a burden on the entire community that the kafil represented. It was often the local notables holding official administrative positions (āqsaqual/kathkhudāanāab) who acted in this capacity and thus provided "donative liability"145 to individuals who confessed to felonies such as murder and robbery. ${ }^{146}$

\section{Colonialism, Orientalism and the Study of Sharīa}

From the first years of Russian rule in Central Asia, it was widely claimed that shari $a$ there had always functioned as a legal domain controlled exclusively by the legists. As we shall see in the next chapter, military officials, bureaucrats, and scholars all had reason to claim that the $q \bar{a} d \underline{t} \bar{\imath}$-centric sharîa $a$, as observed under Russian rule, was an exact continuation of what had existed before the conquest of Central Asia. Writing in 1909, Privy Councillor Count Pahlen described imperial policy as follows:

When we subjugated Turkestan, the Russian government adopted the principle of preservation [polazhila printsip sokhraneniia] with regard to

144 Muḥammad Yūsuf Bāy ibn Pahlavān Maḥram to the yasāwulbāshī in Khiva, 25 Dhū al-Qā̄da 1334/23.09.1916, TsGARUz, f. I-125, op. 1, d. 498, 1l. 57. It proved impossible to establish the location of the robbery, because the victim is not identified by his place of origin or residence, but as belonging to a community (qawm) called Sārt Ālācha and administered by an àqsaqāl.

145 I here employ the terminology of Hallaq, Sharía: Theory, Practice, Transformations, 258.

146 For instructive cases in which àqsaqāls and kathkhudās acted in the capacity of "guarantors," see the following reports of conflict resolution in Khorezm: Muhammad Yūsuf Bāy b. Pahlavān Maḥram to the yasāwulbāshī in Khiva, 12 Dhū al-Q̄āda 1336/19.08.1918, TsGARUz, f. I-125, op. 1, d. 498, l. 87-87ob; Muḥammad Ya‘qūb Bāy b. Jabbār Qulī Maḥram to the yasāwulbāshī in Khiva, 22 Jumādī al-Thānī 1335/15.02.1917, ibid.: l. 111. 
the native courts of the indigenes and introduced those changes from which the population would benefit and which would diminish their fanaticism, thereby allowing for a merger with the Russians. ${ }^{147}$

Russians molded the juridical field of sharîa into the system of "native courts" (narodnyi sud), that is, courts presided over by Muslim legal scholars who would enjoy access to this position through elections via ballot. In this way, the colonial administration retained only Muslim jurists, while it overhauled the larger legal context and web of power relations in which such jurists were formerly embedded. ${ }^{148}$

By operating this way, the Russians not only stripped local rulers of their legal powers but also denied that Muslim rulers had ever been qualified to administer justice. The imperial enterprise of reconstructing the mechanics of sharîa in colonial Central Asia was, on the one hand, useful for a project of cultural transformation ${ }^{149}$ and, on the other, integral to an edifice of knowledge that was predicated on the assumption that law was the domain of the professional legists alone. Much of the colonial staff was engrossed in the mundane occupations of administration and was thus not absorbed in Central Asian legal history. Russian imperial administration was not monolithic, as officials everywhere spoke in many voices, but, when colonial masters at times conceded that, in earlier periods, local rulers did intervene in judicial affairs, they usually held that local power-holders could practice justice only "in an arbitrary way." ${ }^{\prime 150}$

When they did not caricature Muslim rulers' prominent role in the juridical field, colonial officials merely ignored its importance. One eloquent illustration is provided by the unpublished work of the famous Orientalist Vladimir

147 Otchet po revizii Turkestanskogo kraia po Vysochaishemu poveleniiu Senatorom Gofmeisterom Grafom K.K. Palenom. Narodnye Sudy Turkestanskogo Kraia (St. Petersburg: Senatskaia Tipografia, 1909): 6 .

148 [Aleksandr K. Geins], Sobranie literaturnykh trudov Aleksandra Konstantinovicha Geinsa (St. Petersburg: Tipografiya Stasyulevicha, 1898): 1:466; N.S. Lykoshin, "Kazii (Narodnye sud'i): Bytovoi ocherk osedlogo naseleniia Turkestana." In Russkii Turkestan: Sbornik 1. Prilozhenie $k$ gazete "Russkii Turkestan" (Tashkent: Tipografiia "Russkii Turkestan," 1899): 53 .

149 W.B. Hallaq, "On Orientalism, Self-Consciousness and History." ILS 18/3-4 (2011): 404.

150 N.A. Khalfin, Rossiia i khantsva Srednei Azii (pervaia polovina XIX veka) (Moscow: Nauka, 1974): 12; I.F. Kostenko, Sredniaia Aziia i vodvorenie v nei Russkoi Grazhdanstvennosti (St. Petersburg.: Tip. B. Bezobrazov, 1871): 63. For British India, see R. Singha, A Despotism of Law: Crime and Justice in Early Colonial India (New Delhi: Oxford University Press, 1998): 27 . 
Viiatkin, which is devoted to the cultural history of the Shibanid empire ${ }^{151}$ and includes a section on the local judicial system. ${ }^{152}$ Viiatkin probably did not know that royal courts in Bukhara, Khiva, and Kokand had administered justice. His study is based on an unknown text on Islamic judicial ethics (referred to vaguely as adab al-qā $d \bar{l})$ and three early-modern notary manuals: the copybook of a late sixteenth-century Samarqandi $q \bar{a} d \underline{\imath} \bar{l}^{153}$ the Mukhtār al-ikhtiyār 'alā al-madhhab al-mukhtār by Ikhtiyār al-Dīn b. Ghiyāth al-Dīn al-Ḥusaynī,

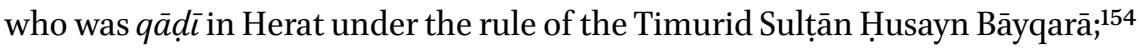
and the otherwise unidentified Shurūt-i arangī. The system of conflict resolution, which Viatkin calls shariat, shows the $q \bar{a}$ dìs and the muftis as the only officials who performed judicial duties under the rule of the khans.

Russians presented the establishment of the native courts of justice as a twofold achievement: first, the purported preservation of the status quo and, second, the creation of a more rational legal system freed from discretionary powers of the local rulers over justice. ${ }^{155}$ Orientalists were fully implicated in

151 The Shibanid/Abulkhairid dynasty ruled Central Asia throughout the sixteenth century; see R.D. McChesney, "Shībānī Khān and Shībānids." In EI2 vol. Ix: 426 ff. and 428 ff.

152 V.L.Viiatkin, Kvoprosam izucheniia uzbekov v Srednei Azii (XVI vek) (written in Samarkand 1932), unpublished manuscript (150 folios), TsGARUZ, f. R-2773, op. 1, d. 1103, ll. 1-37.

153 Majmū a-yi wathä’q, Ms Tashkent, TsVRUz, no. 1386. The text is a formulary manual consisting of 737 copies of legal texts notarized between the years 996/1588 and 999/1591 at the court of Mawlanā Șiddiq al-Halwā̄ì, the deputy of the chief judge. It was entrusted to Viatkin by the $q \bar{a} \mathfrak{d} \bar{\imath}$ of Urgut in 1907. A few of Viatkin's translations were published as Kaziiskie dokumenty XVI veka, ed. R.R. Fitrat and K.S. Sergeev (Tashkent: Komitet Nauk Uzbekistana, 1937). A selection of texts from the Majmü'a-yi wathä'iq appeared in Uzbek translation as Vasiqalar to'plami. (XVI asrining ikkinchi iarmi Samarkand oblastidagi iuridik dokumentlar), ed. B. Ibrohimov (Tashkent: Fan, 1982). The manual has been used also by Rozaliia Galievna Mukminova for her Sotsialnaia differentsiatsia naseleniia gorodov Uzbekistana $v X V-X V I v v$. (Tashkent, Fan: 1985). Muzaffar Alam has noted correctly that some of Mukminova's translations of texts from the Majmü'a-yi wathā’iq are defective. See his "Trade, State Policy and Regional Change: Aspects of Mughal-Uzbek Commercial Relations, c. 1550-1750." JESHO 37/3 (1994): 202-27, ns. 3, 14, 15.

154 Muzaffar Alam, The Languages of Political Islam: India, 1200-180o (Chicago: University of Chicago Press, 2004): $5^{2}$. Alam lists only one manuscript copy preserved in Patna, though an earlier one is held in the Bodleian Library; see Fraser 234, 235, 239. This manual seems to have been used widely in Central Asia, up to the early twentieth century: other copies of this work (including the one examined by Viiatkin) have recently been discovered in the manuscript library of the Institute of Oriental Studies in Tashkent. One of them was probably inspected by Ol'ga Chekhovich, who translated a few passages, TsGARUz, R-2678, op. 1, d. 379 .

155 See Chapter 2. 
this cultural project. This is clearly visible in Russian imperial and early Soviet Central Asia, where experts in vernacular languages and the history of Islamic culture wrote on shari $a$ by creatively extrapolating from what they saw in the "native courts." One such case is provided by Nil Sergeevich Lykoshin (1860-1922), who devoted an entire work to the qādīs in Russian Central Asia, which was based on his participating observation as police chief (pristav) in the Muslim-majority neighborhoods of Tashkent. Lykoshin explains that the native courts among the settled population of Turkestan replaced (smenil) the earlier legal system, which consisted exclusively of $q \bar{a} d \bar{c} \bar{s}$, on whose will the life of the people depended. He emphasizes that the institutional changes introduced by the Russians in Islamic law amounted merely to restricting the competencies of the former $q \bar{a} d \bar{l} \bar{s}$ : a few offenses were subsumed by other legal jurisdictions, and corporal punishment was abolished. ${ }^{156}$

In other cases, we observe Orientalists pushing their informants to recount a story precisely according to their preferred themes. During field work in Bukhara, a group of Soviet academics led by the famous ethnographer and linguist Mikhail Andreev ${ }^{157}$ approached a former expert of the Islamic law of inheritance (tarīkachì), who had worked as attendant at the royal court, and asked him to write down the duties of the chief judge or market inspector $\left(\mathrm{ra}^{3} \mathrm{is}\right) .{ }^{158}$ Their questions were invariably based on the assumption that the late-Manghit judiciary exercised a monopoly over the articulation and execution of justice. ${ }^{159}$ Little wonder, then, that the insider's account was accommodated within a set of conceptions foreign to local judicial practices. ${ }^{160}$ By contrast, an account of the judicial system in Khiva under the Qunghrats—-the

156 See his "Kazii (Narodnye sud'i): Bytovoi ocherk osedlogo naseleniia Turkestana": 53 .

157 K.F. Akramova and N. Akramov, Vostokoved Mikhail Stepanovich Andreev (nauchnobiograficheskii ocherk) (Dushanbe: Irfon, 1973). I owe this reference to Ulfatbek Abdurasulov.

158 Tarjuma-yi aḥwāl-i Qāội Kalānhā-yi darūn-i Bukhārāa, TsGARUz, R-2678, op. 2, d. 251, 6ob-4. The informant was a certain Qārī Aḥmad, who had assisted Bukharan judges.

159 N. Fioletov, "Sudoproizvodstvo v musul'manskikh sudakh (sudy kaziev) Srednei Azii." Novii Vostok 23-24 (1928): 204-17.

160 One of the results of this ethnographic expedition to Bukhara was the monograph by M.S. Iusupov, Sud v Bukhare. Sudoustroistvo i sudoproizvodstvo v Bukharskom emirate $v$ kontse XIX i nachale XX v.v. (written in Samarkand, 1941) (unpublished manuscript, 305 folios), Ms Samarqand, AMIKINUz, no. 828. Though Iusupov notes in passing that the emir himself decided on the appeals of his subjects and on the reports (ll. 15-16), he did little to investigate the procedures according to which Bukharans filed their claim with the royal court and focused, instead, on the $q \bar{a} d \underline{\imath} \bar{s}$ and their courts. 
production of which was not, apparently, prompted by Soviet academicsconferred on the royal court a central role in the resolution of conflict. ${ }^{161}$

One should avoid generalizations in speaking of Orientalists and Islamic legal studies. Many experts in Islamic law who were "educated in the textualist, mostly German, philological tradition"162 advocated the study of doctrinal texts and thus understood sharîa as a law of jurists. In their view, sharîa was a legal doctrine whose evolution depended solely on the muftis as legal theorists, while $q \bar{a} d \bar{\imath}$ s were merely technicians responsible for reconciling doctrine with the extralegal circumstances of the moment. The Orientalist scholarship on Islamic law circulating in the Russian Empire, most of which in the colony was of European origin, is no exception. ${ }^{163}$ It had little impact, however, on the way Russians conceived of the "native courts." For them it was the qā $d \bar{\imath}$ who was primarily accountable for the implementation of sharía.

161 Bābājān Safaruf [Babadzhan Safarov], Khwārazm ta’rīkhī (1864-1934), Ms Tashkent, TsVRUz, no. 10231, in particular the section entitled "Practices of solving disputes submitted to the rulers, the office holders and the governors" (khān 'amaldārlār hāakimlārnīng birgāndān [?] da'wā janjāllārnì muhākama qülīsh 'ādatlārì), fols. 21-23. The author was born at the end of the nineteenth century in Khiva, studied in a local madrasa, and worked as mufti under the Qunghrats. See Sobranie vostochnykh rukopisei Akademii Nauk Uzbekistan. Istoriia, ed. D.Iu. Iusupov and R.P. Dzhalilov (Tashkent: Fan, 1998): 236. That he served in some juristic capacity can be inferred from a request for a legal opinion that he sent to Bukhara in 1919; see B. Kazakov, Bukharan Documents: The Collection in the District Library, Bukhara, trans. J. Paul (Berlin: Klaus Schwarz, 2001): 44.

162 I. Agmon and I. Shahar, "Theme Issue: Shifting Perspectives in the Study of Shari'a Courts: Methodologies and Paradigms." ILS 15/1 (2009): 4 .

163 For an overview of the available literature at the beginning of the twentieth century, see A.E. Krymskii, "O posobiiakh dlia izucheniia musul'manskogo prava." In Istoriia musul'manstva. Somostoiatel'nye ocherki, obrabotki $i$ dopol'nennye perevody iz Dozi $i$ Gol'dtsiera, ed. A.E. Krymskii (St. Petersburg: Tipogr. V. Gattsuk, 1904): part II, 28-38. As late as 1912, the Orientalist Nikolai Ostroumov noted that, "with regard to Islamic studies and most notably to the study of Islamic jurisprudence, the Russian scholarship (russkaia pechat') deserves to be reproached. It is impossible to rule 20 millions of Muslims, not only without knowledge of shärīa but also without acknowledging the latter's necessity"; see his Islamovedenie. 4. Shariat po shkole (mazkhab) Abu-Khanify (Tashkent: Tip. Pri Kants. Turk. Gen.-Gub, 1912): 19. On Ostroumov, see B. Babajanov, “'How Will We Appear in the Eyes of Inovertsy and Inorodtsy?' Nikolai Ostroumov on the Image and Function of Russian Power." CAS 33/2 (2014): 270-88. Babajanov here overlooks the fact that, in spite of his misuse of the word "code" for sharīa, Ostroumov clearly understood that the application of Islamic law depended on the interpretive role of the jurists (muftis); hence, it is to Ostroumov that we owe the first comprehensive list in Russian of authoritative juristic sources employed by local muftis: Ostroumov, Islamovedenie. 4: 9-18. 
Another problem we may face in examining scholarship in Islamic legal studies and sharía in precolonial Central Asia is the assumptions we bring to the concept of governing authorities or "the state." Considering a region of the Muslim world such as Central Asia in the nineteenth century may lead us to situate the local khanates in a wider history of modernization and a narrative of cultural change in which Muslim polities translated their encounter with the West into their own experiences of modernity. This may risk our assuming that modernizing trends current-for example, in the Ottoman Empire during the Tanzimat period - prevailed also in Khiva, Bukhara, and Kokand. Central Asian legal history is completely different. The Muslim polities that governed there did not display the sorts of reforms or the cultural orientations that were current in the Ottoman Empire in the second half of the nineteenth century: we find few attempts at the formalization and proceduralization of judicial activities, and we cannot cite instances of codification similar to the qānūnnāmas and legal transplantation of, say, Western legal texts. ${ }^{164}$ In Central Asia we do, however, see forms of "corporate identity" and "a public welfare apparatus," as well as "a universal administrative and bureaucratic control"165 and instruments of "surveillance, discipline, and punishment," all features that Wael Hallaq considers intrinsic to the model of the modern nation state, under the rule of which sharita lost its pristine functions and was eclipsed.

According to Hallaq, modernizing trends in the Muslim world began in the Ottoman Empire as an endemic process of centralization - itself a measure to counteract the military and economic power of the West-and then affected much of the Muslim-majority colonies. Under these conditions, shari'a became subjected progressively to the legislative ethos of states that imposed their own juristic views. The modern state and sharīa are, in Hallaq's view, incompatible, because both represent two "machines of governance" that tolerate no external infringements aimed at "determining the substance of law."166

There are two problems with the way Wael Hallaq approaches the study of sharîa in the modern period. First, he leads us to view the centralization of

164 See A. Rubin, Ottoman Nizamiye Courts: Land and Modernity (New York: Palgrave MacMillan, 2011).

165 W.B. Hallaq, "Islamic Law: History and Transformation." In The New Cambridge History of Islam, vol. 4, Islamic Cultures and Societies to the End of the Eighteenth Century, ed. Robert Irwin (Cambridge: Cambridge University Press, 2010): 143 .

166 W.B. Hallaq, Sharĩa: Theory, Practice, Transformations (Cambridge: Cambridge University Press, 2009): 361 . 
the judicial apparatus as a centripetal force, by which sharía is driven from the landscape it originally inhabited. The idea that shari $a$ was centrifugal to the state is misleading for the legal history of Central Asia and the wider Hanafi world. Muzaffar Alam has shown how attempts to rethink the relationship between sharî $a$ and the state are visible in Herat under Shāhrukh in the first half of the fifteenth century and later under Bābur (r. 932-37/1526-30).167 This became an even stronger phenomenon in the late eighteenth century and throughout the nineteenth - or at least we have more sources that attest to it. This phenomenon has nothing to do with the encounter with the West. More than a century before Awrangzeb (r. 1068-1118/1658-1707) solicited the compilation of the collection of legal opinions called al-Fatāwa al-Ālamgíríya, the first ruler of the Abu 'l-Khayrids in Bukhara commissioned the compilation of the al-Fatāwā al-Shībannōya in Persian, which would have been easily intelligible to the local populace. ${ }^{168} \mathrm{~A}$ few decades later, Shāh 'Abbās commissioned the imposing Jāmi $i$ ' $A b b \bar{a} s \bar{l}$ to popularize the Shici legal literature in the vernacular, so the Persianate world witnessed, between the sixteenth and seventeenth centuries, several attempts by sovereigns to define the Islamic legal domain. ${ }^{169}$

The other problem is that, in distinguishing between the state, as a preserve of legal authority, and the judiciary, one makes an a priori distinction between two entities that are actually of the same substance: most of the people who staffed the chancellery of the khanates - the administrative apparatus of local Islamic polities — had the same background as the jurists who were appointed to the post of $q \bar{a} d \bar{\imath}$ or worked as muftis. Rulers themselves, for example, were often jurists or were surrounded by legists such as the yasāwul-i ulama $\bar{a}$. 'Ulam $\bar{a}$ ' staffed the chancelleries of the khanates and taught in the madrasas established by local dynasts. The state and whatever legalistic knowledge emanates from it should not necessarily be regarded as different from or opposed to the production of the 'ulam $\bar{a}$. Drawing an artificial boundary between the state and the sharía (or the 'ulamä) risks applying the notions of legal diversity to a juristic field that contained only one body of law. In Central Asia,

167 Alam, The Languages of Political Islam: India, 1200-180o: passim.

168 ammā ba'd: chunin gūyad al-faqīr [ followed by the name of the author, P.S.] ki bā'ith bar tahrīr-i ìn kalamāt wa taqrīr-i ìn maqālāt ān-ast ki hadrat-i șāhib-qirān-i nādir-zamān ìn faqür-i shikasta-yi durust-i'tiqād rā amr kard ki kitābì bar bāb-i masāyil-i shar'ìya-i far'īya nawīsad ki qaīb ba-fahm wa ma'mūla bihi bāshad tā bar jamī-i mustafìdān-i ān āsān bāshad, 'Alī b. Muḥammad 'Alī b. 'Alī b. Maḥmūd al-Mukhtārī al-Khwārazmī al-Kubrawī, al-Fatāwā al-Shībānīya, ms Tashkent, TsVRUz, no. 6112/1: fols. 7a-7b. Described in sVR VIII: 290.

169 R. Jurdi Abisaab, Converting Persia: Religion and Power in the Safavid Empire (London: I.B. Tauris, 2004): 58 . 
the subjects of the khanates distinguished between the royal court and the $q \bar{a}$ dìs as different legal venues. But they did so only on account of an asymmetry of powers of enforcement rather than because of procedural differences.

The literature on the state's legal administration is narrow, and nearly all of it is surprisingly similar: the justice of the royal court is either substantively different from sharita as it deals with the reparation of offenses that do not fall within the jurisdiction of the $q \bar{a}$ dīs, or it is referred to as mazālim, which serves as a court of second instance. ${ }^{170}$ To the best of my knowledge, a recent work by Yossef Rapoport is unique in having approached the relationship between the royal court and sharîa from a different perspective. In a study addressing the purported deterioration of the Islamic legal system under the Mamluks, Rapoport has argued that "the mazălim courts of the pre-Mamluk classical tradition $[\ldots]$ were $[\ldots]$ transformed into courts of wide jurisdiction, parallel to the sharíah courts of the qadis. These new institutions were called siyassah courts, because of their emphasis on equity at the expense of the formalism of the sharīah. [...] The siyasah courts of the fifteenth century had jurisdiction over cases that had little direct effect on public policy, such as reclamation of debts and matrimonial cases." ${ }^{\text {171 }}$ Rapoport's contribution in opening new lines of inquiry into the entanglement of shari $a$ with the justice emanating from the royal court is twofold: he shows that the $q \bar{a} d \bar{l} \bar{s}$ and the magistrates of the ruling principalities were complementary, and he demonstrates an increasing tension between the two as the establishment of the institutions of "siyassah courts" signaled a centralization of legal administration that culminated in the interference of the rulers in the way $q \bar{a}$ ḍis resolved disputes. The centralized Ottoman administration is usually held up as the sole case in which such tension was resolved by the ruler by means of the qānūn, that is, a medium for reconciling sharîa to the ruler's law.

Elaborating further on Rapoport's argument, I propose that the justice of the royal court and sharita are not merely complementary but are one and the same thing. First, we have seen that, in nineteenth-century Central Asia, Islamic law was not administered only by a professional judicial body. I hope to have shown that, after the fall of the Ashtarkhanids and the Abu 'l-Khayrids (1747) and the subsequent establishment of the three main ruling principalities, the administration of law underwent bureaucratization and centralization that led to a greater involvement of the royal court in people's private affairs. The archives of the Manghit (r. 1753-1920), Ming

\footnotetext{
170 Ben-Bassat, Petitioning the Sultan: Protesters and Justice in Late Ottoman Palestine: 24-8.

171 Y. Rapoport, "Royal Justice and Religious Law: Siyāsah and Sharīah under the Mamluks." MSR 16 (2012): 75 .
} 
(r. 1798-1876), and Qunghrat (r. 1770-1920) bureaucracies suggest that qādīs more often than not served in the humble capacity of legal advisors and were thus held accountable for every decision they took. If we move away from records produced only for patterns of private consumption - which, according to the Soviet academic taxonomy, are usually termed "qadi documents") ${ }^{172}$ we see that Central Asians living under the rule of the Muslim principalities accessed the legal services provided by the royal court, which may or may not have required the legal expertise of $q \bar{a} d \bar{i} \mathrm{~s}$.

Second, the fact that nineteenth-century jurists issued opinions that conferred legitimacy on the view that $q \bar{a}$ dìs should submit to the will of the local ruler means that manifestations of dependence on the ruling house were becoming an established feature of the Islamic juridical field in Central Asia. ${ }^{173}$ That opinions were issued on this point of law also suggests that the dependence of the 'ulamã' on the rulers was disputed among legal experts. ${ }^{174}$

\section{On Customary Law}

In examining the historiography of law in post-Mongol Central Asia and considering the state, we have to deal with an additional complication that requires a specific, though cursory, treatment. It is often assumed that Central Asian khanates occasionally operated in a legal field different from sharîa, which somehow represented the cultural legacy of the Mongols. Chinggis Khan is known, among other things, for having been a lawgiver who introduced a body of customary laws called the yasa (jasaq). There is no way to establish what the yasa was during Chinggis Khan's time, because the available sources referring to his regulations were produced centuries later. ${ }^{175}$ Things are no easier in the Timurid period in attempting to evaluate the törä, a term Maria Eva

\footnotetext{
172 A translation of the Russian kaziiskie dokumenty (Uzbek, qozi hujjatlari).

173 J. Pickett, The Persianate Sphere during the Age of Empires: Islamic Scholars and Networks of Exchange in Central Asia, 1747-1917. PhD diss. (Princeton University, 2015): chap. 5.

174 For an argument against the submission of the 'ulama $\vec{a}$ ' to the Manghit ruling house, see Ahmadi Donish, Navodir-ul-vaqoe", ed. A. Devonaqulov, 2 vols. (Dushanbe: Donish, 1988-9): 2:53-4.

175 R.G. Irvin, "What the Partridge Told the Eagle: A Neglected Arabic Source on Chinggis Khan and the Early History of the Mongols." In The Mongol Empire and Its Legacy, ed. R. Amitai-Press and D. Morgan (Leiden: Brill, 1999): 10; D. Morgan, "The 'Great Yasa of Chinggis Khan' Revisited." In Mongols, Turks, and Others: Eurasian Nomads and the Sedentary World, ed. R. Amitai and M. Biran (Leiden: Brill, 2005): 305-7.
} 
Subtelny explains as the "Turko-Mongolian custom as practiced by Temür, his descendants, and their Chaghatay[-speaking] followers," which "overlapped and complemented the Chinggisid yasa."176 One of the elements connecting the Timurid törä directly to Chinggisid customary law is said to be the $y \overline{a r g h} \bar{u}$, the "court of investigation," which Subtelny describes as "the chief instrument of enforcement of the yasa."177 References to the törä and the yārghu in Timurid sources, however, convey rather a perceived tension between the latter and the sharí $a^{178}$ than a reflection of how the yasa and the törä actually functioned. By the nineteenth century, yārghü had acquired a completely different meaning and was applied to punishments meted out by the royal court. ${ }^{179}$

Thomas Welsford has made a strong case that the Mongol yasa and the Timurid törä were nothing other than instruments to invoke Chinggisid traditions, "however contextually understood. Because there was no authoritative record dating back to Chingiz's own rule, people knew of a 'Chingizìd tradition' only in the form of its various late avatars, each articulating a world-view somewhat different from the next."180 This interpretation holds true also for later periods. As Anke von Kügelgen has noted, Manghit historiographers repeatedly praised their patrons for having abolished "Chinggisid innovations" (bid'athā-yi chingizzi $)$ which consisted largely of forms of taxation other than those sanctioned by sharīa ${ }^{181}$ The Khivan chroniclers Munīs and Āgahī do

176 Subtelny, Timurids in Transition: $15^{-16 .}$

177 Ibid.: 21. Another sympathizer with this view is Jürgen Paul, in Zentralasien (Frankfurt am Main: Fischer, 2012): 317.

178 Subtelny, Timurids in Transition: 25; İ. Togan, "Uluğbek zamanında Yasa ve Şeriat Tartışmaları." Tarih Çevresi 1 (1994): 9-16; İ.E. Binbaş, "The Anatomy of a Regicide Attempt: Shāhrukh, the Hurūfiss, and the Timurid Intellectuals in 830/1426-27." JROAS 23/2 (2013):33.

179 Aḥmad Makhdhūm Dānish Muhandis-i Bukhārī, alias Aḥmad-i Kalla, Tarjimat al-aḥwāl-i amīrān-i Bukhārā-yi sharīf az Amīr-i Dānyāl tā 'așr-i Amīr 'Abd al-Ahad, Ms Tashkent, TsVRUz, no. 1987: fol. 15b; Maktūbāt-i Amīr Haydar ba Muhammad Hakīm Bī, Ms Tashkent, TsVRUz, no. 2120: fol. 304a (yasāwul rā 'afw farmūdìm bāyad ki tahṣilldārān az way yarghū țalab nasāzand); Semenov, Ocherk ustroistva tsentral'nogo administrativnogo upravleniia Bukharskogo khantsva pozdneishego vremeni: 13. Jürgen Paul claims that the yārghū continued to exist after Shāhrūkh, although he provides no evidence in support of this statement, Zentralasien: 317.

180 T. Welsford, Four Types of Loyalty in Early Modern Central Asia: The Tūqūy-Tīmūrid Takeover of Greater Mā warā al-Nahr, 1598-1605 (Leiden: Brill, 2012): 85.

181 Von Kügelgen, Die Legitimierung der mittelasiatischen Mangitendynastie in den Werken ihrer Historiker: $270-2$. 
the same, when they recount how Eltüzer Khān Qunghrat abrogated similar "unlawful innovations" in taxation in Khorezm. ${ }^{182}$

It follows that, if there was in early-modern Central Asia a legal field that might have been different from Islamic law and fallen under the jurisdiction of the ruling house alone, it must have been the $y \bar{a} r g h \bar{u}$, which disappeared, however, with Shāhrukh, if we are to credit the reconstruction made by Subtelny. By contrast, starting in the sixteenth century, texts occasionally refer to "Chinggisid" legal practices that deviate from Islamic law. It does not necessarily follow that such practices represented a Turko-Mongolian customary law or a kind of justice administered by the state.

In the attempt to move away from a statist perspective, historians of Islamic law (most notably students of Ottoman history) have sought to show not only that the courts applying shari $a$ enjoyed a certain degree of autonomy from the state but also that their judicial operations were effectively informed by principles of "collective responsibility and self-government."183 In emphasising, instead, close ties between sharía courts and the state, my argument might be accused of resurrecting an interpretive paradigm that was abandoned long ago. Against this objection, I should note that my study develops the idea that Central Asian khanates did not claim legislative prerogatives for themselves. They never legislated on matters of sharía law, nor did they attempt to codify it. By promoting forcefully a theory of justice that rested on the defense of shari $a$, the khanates drew upon notions of local practice, custom, and collective responsibility. This inclusive aspect of the state rests uncomfortably on a narrative of opposition between legal centralism and autonomous legal fields. I thus situate the state in a juridical field in which all legal actors use shari' $a$ as a common set of legal values to translate the particular into the universal. Judges, along with cultural brokers, saints, and people endowed with local knowledge, were all expected to act according to sharīa $a$. The khanate watched and held everyone accountable.

182 Shīr Muḥammad Mīrāb Mūnis and Muḥammad Rizā Mīrāb Āgahī, Firdaws al-iqbāl: History of Khorezm, trans. Y. Bregel (Leiden: Brill: 1999): 183-84. There is a striking similarity, however, between Shah Murād, Eltüzer Khān and Shāhrukh, who are all praised for having restored sharía by abrogating unlawful forms of taxation (qālanāt); see M.E. Subtelny, "The Sunni Revival under Shār-Rukh and Its Promoters: A Study of the Connection between Ideology and Higher Learning in Timurid Iran." In Proceedings of the 27 th Meeting of Haneda Memorial Hall Symposium on Central Asia and Iran August 30, 1993 (Kyoto: Institute of Inner Asian Studies, 1993): 20.

183 B.A. Ergene, Local Court, Provincial Society and Justice in the Ottoman Empire:Legal Practice and Dispute Resolution in Çankırı and Kastamonu (1652-1744) (Leiden: Brill, 2003): 24. 
It may be useful to revisit, briefly, the meaning of customary law in the Russian period, especially because we shall come across this category in the following chapters. Received wisdom on law and colonialism holds that the Europeans "invented" customary law by requesting that indigenous experts commit to writing down the laws that they followed locally and that had previously existed only in oral form. Colonial "invention" of customary law took other forms also. Russian officials, for example, were directly engaged in their collection and recording and thereby acted as legal anthropologists. In the Caucasus, Russians assembled books of village rules, in Arabic, and in Central Asia they compiled digests of customary laws, mainly in Russian (erezhe/ sbornik obychaev). In both cases, the "invention" of customary law amounted to a purposeful disambiguation of certain norms from a larger system of legal signification in which they had previously been entangled. ${ }^{184}$ In both the Caucasus and Central Asia, the compilation of books of customary law and their extended commentary in the Russian press was integral to an imperial policy aimed at disempowering sharía among specific Muslim communities in the hope that it would facilitate their subjugation. Virginia Martin observes that:

The diverse collections of rules and principles that were presented for government use or published in the periodical press were identified collectively as the "customary law" (obychnoe pravo) of the Kazakhs. In this way, Russian officials and scholars "invented" Kazakh customary law and gave it claim to universality. They produced a body of written customs that may have captured many of the judicial practices of a particular kinship group or region at a particular time, but once recorded[,] the oral customs ceased to accurately reflect changing, everyday practices. ${ }^{185}$

184 R. Roberts and K. Mann, "Law in Colonial Africa." In Law in Colonial Africa, ed. K. Mann and R. Roberts (Portsmouth, NH: Heinemann, 1991): 4; M. Chanok, "Paradigms, Policies, and Property: A Review of the Customary Law of Land Tenure." In ibid.: 61-84. M. Kemper and M. Reinkowski, "Einleitung: Gewohnheitsrecht zwischen Staat und Gesellschaft." In Rechtspluralismus in der Islamischen Welt. Gewohnheitsrecht zwischen Staat und Gesellschaft, ed. M. Kemper and M. Reinkowski (Berlin and New York: De Gruyter, 2005): 2-3; B.M. Cooper, "Injudicious Intrusions: Chiefly Authority and Islamic Judicial Practice in Maradi, Niger." In Muslim Family Law in Sub-Saharan Africa: Colonial Legacies and Post-Colonial Challenges, ed. S. Jeppie, E. Moosa, and R. Roberts (Amsterdam: Amsterdam University Press, 2010): 183-218. A. Guerin, "Racial Myth, Colonial Reform, and the Invention of Customary Law in Morocco, 1912-1930." The Journal of North African Studies 16/3 (2011): 361-80.

185 Martin, Law and Custom in the Steppe: The Kazakhs of the Middle Horde and Russian Colonialism (Richmond, UK: Curzon, 2001): 4. 
Any process of codification is an attempt to fix specific norms, to confer normative value on them, and, probably, to exclude other norms deemed unsuitable under changing social circumstances. This is not characteristic only of colonial governmentality. Muslim jurists, too, produced books of substantive law, such as collections of fatwas and abridged legal manuals (mukhtașar), ${ }^{186}$ in order to endow with authority specific modes of juristic reasoning and certain judicial procedures, with the effect that they gave the latter claim to universality. ${ }^{187} \mathrm{The}$ use of terms such as dastür and 'urf, which we often find in vernacular deeds in Central Asia, is no less a cultural construction - that is, an ex post facto categorization adopted to confer on a given practice, whether well established or not, the force of custom.

Also, Paul Dresch ${ }^{188}$ and Judith Scheele ${ }^{189}$ cite the need to distinguish between invented custom and nonstate forms of legalism manifesting themselves in the colonial period that cannot be reduced to colonial "inventions" and Western impositions. Both have argued that emphasis on the invention of customary laws does more to obscure than to clarify the meaning of the laws or normative orderings that we call "customary." I agree with Dresch and Scheele that little has been done so far to understand how Kazakh customary law functioned and how its practitioners and consumers conceived of it.

There are two aspects of customary law in colonial Central Asia that should be addressed further. First, it seems that, for Kazakh arbitrators (bīs), it was of little concern that they operated in courts established by the Russians to dispense justice under a legal system that today we tend to dismiss as a colonial "invention." Either they considered irrelevant what they recorded in court registers and thus catered to the expectations of the Russian administration, or, more likely, they were perfectly at ease with the new institutional arrangement of the customary law courts and thus believed that they were operating according to a normative system that ought to be called 'a dat. Kazakh arbitrators may well have regarded with favor the institutional innovation of the native courts in light of their own personal interests. The clientele of the new

186 M. Fadel, "The Social Logic of Taqlìd and the Rise of the Mukhatașar." ILS 3/2 (1996): 193-233.

187 A. Fekry Ibrahim, "The Codification Episteme in Islamic Juristic Discourse between Inertia and Change," ILS 22/3 (2015): 157-220.

188 P. Dresch, "Legalism, Anthropology, and History: A View from Part of Anthropology." In Legalism: Anthropology and History, ed. P. Dresch and H. Skoda (Oxford: Oxford University Press, 2012): 1-37.

189 J. Scheele, "A Taste for Law: Rule Making in Kabylia (Algeria)." cssh 50/4 (2008): 895-919. 
customary-law courts represented a source of income and, as such, clearly increased their power. Some Kazakhs may, however, have viewed customary law less as a colonial invention than as an expression of their own legal culture.

Second, and more significantly, the $b i \bar{s}$ who adjudicated according to customary law among a specific Muslim community could also, if needed, easily change legal hats and act in the capacity of $q \bar{a} \bar{d} \bar{l} \mathrm{~s}$ who would rule according to shari ${ }^{-1}{ }^{190}$ We observe this curious phenomenon in various places in Russian Central Asia. ${ }^{191}$ This originates from the fact that the incorporation of this region into the Russian Empire brought about an "Islamic revival," which manifested itself in the proliferation of institutions of Islamic higher learning (madrasa), where more Muslim students could study and practice sharīa. As a result, we observe, along with procedural differences, a significant overlap of Islamic stock phrases between 'ädat and sharīa courts under Russian rule. ${ }^{192}$

Taken together, these two aspects suggest that Russian imperialism in Central Asia changed the meaning that people gave to custom and ultimately affected their legal consciousness.

\section{Conclusion}

Subjects of the khan filed their claims with the royal court for many reasons. According to a widely shared perception, agencies in Bukhara, Khiva, or Kokand were more powerful than provincial officeholders—-for example, a $q \bar{a} d \bar{l}$ - and the royal court's sanctioning of a ruling would ensure its execution. Materials from early-twentieth-century Central Asia, especially from Khorezm, indicate that $q \bar{a} d \bar{l}$ s lacked even the power to summon parties, as demonstrated by the following record indicating that a respondent used violence against a court attendant:

Mullā Muhamammad Panāh, the husband of Bībī Bỉka, who is the sister of Mullā Jum‘a Niyāz from Khiva, opened her [wife's] chest with a key and stole leather galoshes and valuable clothes. Moreover, he beat the

\footnotetext{
190 Sartori, "The Birth of a Custom: Nomads, Sharīa Courts and Established Practices in the Tashkent Province, ca. 1868-1919": 312.

191 Allen J Frank has noted the same phenomenon, which he terms "an overlap between qadis and biys" among the Kereys of Petropavlovsk. E-mail communication, 26 February 2015.

192 P. Sartori, "Murder in Manghishlaq: Notes on an Instance of Application of Qazaq Customary Law in Khiva (1895)." DI 88/2 (2012): 235-40.
} 
aforementioned Bībī Bīka for no reason and made her suffer. For this reason, the qaḍi ishān appointed Mullā Sayyid Muhamammad as trustee [yasāwul] and sent him [to the place]. [Mullā Muhammad Panāh, however,] beat him too and insulted him. Therefore, the above mentioned [Mullā Jum'a Niyāz] has a claim against Mullā Muhammad Panāh. Let them come to the royal court of his majesty-may his rule last forever - together with the attendant, Raḥman Birgān Bājbān, who is the guard [nawkar] of Muhammad Ya'qūb Bāy Yasāwulbāshī, and resolve the case. They should pay two tangas for each parasang to the attendant. This instruction was written on 6 Rabī‘ al-Thānī in 1336 [19.01.1918]. ${ }^{193}$

Disputing parties who traveled to the seats of power made significant financial investments to file their claim with the authorities. There may have been other reasons for such investments: a desire to shift the case away from local power struggles, to attract the maximum possible publicity for one's case in order to restore public credibility, ${ }^{194}$ or out of distrust for local officeholders. Our sources suggest that local subjects enjoyed the right to request that their cases be transferred to Khiva, for example, even during trials held at the office of a governor or in a $q \bar{a} d \vec{\imath} \mathrm{s}$ court. ${ }^{195}$ The prerogative of subjects living in localities far from center of the khanate to lodge a lawsuit with the royal court thus belonged to a "culture of justice."

In nineteenth-century Central Asia, as elsewhere in the Islamicate world, most claims were heard and resolved informally. My argument- the royal court's prominent role in the resolution of conflicts-accounts for only a fraction of what occurred in villages and provinces, away from the centers of power, where local notables and elders regularly settled disputes. Deeds of acquittal and amicable settlement notarized by $q \bar{a} d \underline{\imath} \bar{s}$, common as they were in Central Asia, probably attest to the resolution of conflicts that first were treated informally, without the aid of a state representative. Informal settlements were integral to the local legal "system," but this observation does not detract from the argument that power relations among state officials affected the practice of Islamic law. Muslims would not bring their affairs to a

193 TsGARUz, f. I-125, op. 1, d. 633, l. 90. A parasang (farsakh) is approximately $5^{1 / 2}$ kilometers.

194 I draw on Daniel Lord Smail's notion of publicity in The Consumption of Justice: Emotions, Publicity, and Legal Culture in Marseille, 1264-1423.

195 TsGARUz, f. I-125, op. 1, d. 498, ll. 44; 56-56ob. 
judge unless ordered to do so by the royal court or a governor. ${ }^{196}$ The local populace knew that qā rulings may, in fact, attest to trials held at the request of a governor or the royal court.

The Central Asian royal courts no doubt devoted attention to the mundane affairs of their subjects while ignoring established judicial practices that were followed in other regions of the Islamicate world, because appeal to the royal court ('ard) served to relieve social tensions. More importantly, however, it gave the central government the opportunity to monitor local affairs in a regular fashion and thus to make timely adjustments in response to changing social circumstances.

196 TsGARUz, f. I-125, op. 1, d. 509, l. 145. This rescript of the dīwānbigi to the khan demonstrates the extent to which Khivan authorities could instruct qā civil-law cases. This is a case of debt: the dīwānbìgi writes to a $q \bar{a} d \bar{c}$, orders him to appoint a trustee (amin), and sends him with a guard to a locality to sell certain possessions to the creditors (14.11.1916). 